A multifunctional photoelectroactive platform for $\mathrm{CO}_{2}$ reduction towards $\mathrm{C}_{2+}$ products - programmable selectivity by a bioinspired polymer coating

Lukáš Děkanovský, ${ }^{1}$ Jan Plutnar, ${ }^{1}$ Jiří Šturala, ${ }^{1}$ Jiř́i Brus, ${ }^{2}$ Jiř́i Kosina, ${ }^{3}$, Jalal Azadmanjiri, ${ }^{1}$ David Sedmidubský, ${ }^{1}$ Zdeněk Sofer ${ }^{1}$ and Bahareh Khezri ${ }^{1 *}$

${ }^{1}$ Department of Inorganic Chemistry, Faculty of Chemical Technology, University of Chemistry and Technology Prague, Technická 5, 16628 Prague 6, Czech Republic

${ }^{2}$ Institute of Macromolecular Chemistry of the Czech Academy of Sciences, Heyrovskeho nam. 2, 162 06, Prague 6, Czech Republic

${ }^{3}$ Central Laboratories, University of Chemistry and Technology Prague, Technická 5, 16628

Prague 6, Czech Republic

*Correspondence: bahareh.khezri@vscht.cz, bahareh.khezri.research@gmail.com 
Table of Content:

8

Figure S1. Polymerization starts rapidly in minutes, followed by fast color change of the solution.

Figure S2. Structure of A) HAP and B) P(DOPA) before and after calcination.

Figure S3. STEM images and EDX elemental mapping of the HAP core material.

Figure S4. STEM images and EDX elemental mapping of the HAP/P(DOPA)2h/Cu composite.

Figure S5. STEM images and EDX elemental mapping of the HAP/P(DOPA)5h/Cu composite.

Figure S6. STEM images and EDX elemental mapping of the HAP/P(DOPA)15h/Cu composite.

Figure S7. HREM images and SAED

Figure S8. Raman and FTIR analysis of the final HAP/P(DOPA)5h/Cu composite.

Figure S9. XPS evaluation of the $\mathrm{Cu} 2 \mathrm{p}$ of the HAP/P(DOPA) $5 \mathrm{~h} / \mathrm{Cu}$ particles and HAP core.

Figure S10. XPS evaluation of the C 1s, O 1s, Ca $2 p$ and P $2 p$ spectra of the pure HAP core. P20

Figure S11. ssNMR analysis of the final HAP/P(DOPA)15h/Cu composite. $\quad$ P21

Figure S12. XRD comparison of the calcinated and noncalcinated HAP/P(DOPA)15h sample.

Figure S13. Cyclic voltammetry (CV) curves at various scan rates $\left(50 \mathrm{mV} \mathrm{s}^{-1}\right)$ for all samples (including blanks) in both EC (black) and PEC (red) analysis modes.

Figure S14. BET analysis of the catalysts.

Figure S15. Linear sweep voltammogram of all samples (including blanks).

Figure S16. Chronoamperometric responses at different potentials.

Figure S17. Selectivity (Faradaic efficiency $\left(\mathrm{H}_{2}, \mathrm{CO}, \mathrm{CH}_{4}, \mathrm{C}_{2} \mathrm{H}_{4}, \mathrm{C}_{2} \mathrm{H}_{6}, \mathrm{C}_{3} \mathrm{H}_{6} \mathrm{O}\right.$ and $\left.\mathrm{C}_{4} \mathrm{H}_{8} \mathrm{O}_{2}\right)$ )

Figure S18. Active surface Area

Scheme S1. Schematic diagram of our home-made electrochemical H-type cell.

Table S1. Table S1. Elemental analysis.

Table S2. Maximum faradaic efficiency of blanks (HAP, HAP/CuO, HAP/P(DOPA)2h, HAP/P(DOPA)5h, $\mathrm{HAP} / \mathrm{P}(\mathrm{DOPA}) 15 \mathrm{~h}$ for each product in both analysis Modes (P/EC)

Table S3. The periodic quantification of products during long-term stability test.

Table S4. The comparison of catalysts based on hydroxyapatite or polydopamine in various $\mathrm{CO}_{2}$ conversion systems. 


\section{Experimental Section/Methods}

Materials: The following materials were obtained: Citric acid (Alfa Aesar), $\left(\mathrm{NH}_{4}\right)_{2} \mathrm{HPO}_{4}$ and $\mathrm{Ca}\left(\mathrm{NO}_{3}\right)_{2} \cdot 4 \mathrm{H}_{2} \mathrm{O}$ (Sigma), $\mathrm{NH}_{3} \cdot \mathrm{H}_{2} \mathrm{O}(24 \%)$ (Penta), TRIS and Dopamine hydrochloride (Fluorochem), $\mathrm{Cu}\left(\mathrm{NO}_{3}\right)_{2} \cdot 3 \mathrm{H}_{2} \mathrm{O}, \mathrm{KHCO}_{3}($ ), $\mathrm{KCl}$ () and Nafion solution 5\% (Sigma).

Synthesis of HAP cores: Synthesis started by dissolving $52.53 \mathrm{~g}$ of citric acid in $250 \mathrm{~mL}$ of demineralized water (DW) by constant mixing $(600 \mathrm{rpm})$ at room temperature, to create a solution A (first Step). In the meantime, the next solution (B) was prepared by dissolving 2.64 $\mathrm{g}$ of $\left(\mathrm{NH}_{4}\right)_{2} \mathrm{HPO}_{4}$ in $100 \mathrm{~mL}$ of DW. the $\mathrm{pH}$ of solution A was adjusted to 10 using $24 \%$ $\mathrm{NH}_{3} \cdot \mathrm{H}_{2} \mathrm{O}$ solution, followed by dissolving $4.72 \mathrm{~g}$ of $\mathrm{Ca}\left(\mathrm{NO}_{3}\right)_{2} \cdot 4 \mathrm{H}_{2} \mathrm{O}$. Solution A was mixed until we reach the complete dissolution of the Ca precursor. Later, a condenser was fitted to the flask with solution A. After that, solution B was slowly added to solution A under vigorous mixing and the flask was placed in an oil bath with the temperature set to $70^{\circ} \mathrm{C}$. The reaction was kept under constant temperature and stirring $\left(70^{\circ} \mathrm{C}, 400 \mathrm{rpm}\right)$ for $24 \mathrm{~h}$. The final solution was vacuum-filtrated and washed with DW using nylon membranes with $0.45 \mu \mathrm{m}$ pore size. Each $100 \mathrm{~mL}$ of the solution was washed with $200 \mathrm{~mL}$ of hot $\mathrm{DW}\left(60^{\circ} \mathrm{C}\right)$ on membranes. Purified HAP cores on the membranes were dried for $24 \mathrm{~h}$ under vacuum for further usage $\left(35^{\circ} \mathrm{C}\right)$.

Surface coating with $P(D O P A)$ : Typical coating process was performed by sonication of 0,15 g HAP cores in $120 \mathrm{~mL}$ of DW for 5 minutes. Then, $181.44 \mathrm{~g}$ of TRIS salt was added to the solution and dissolved (400 rpm, $5 \mathrm{~min}$.). The coating process was started by adding $0.3 \mathrm{~g}$ dopamine hydrochloride to the solution. Quick sonication for 2 minutes followed by adjusting the $\mathrm{pH}$ by $0,1 \mathrm{M} \mathrm{NaOH}$ to the 8.5 and then the coating process started. This reaction can quickly change the color from white to pink-brown, and finally the forming of P(DOPA) is characterized by a dark black color. The reaction was kept under constant stirring ( $400 \mathrm{rpm}$ at RT) for 2,5 , or $15 \mathrm{~h}$, respectively. P(DOPA)2-15h coated HAP cores were vacuum-filtered 
(nylon membranes with $0.45 \mu \mathrm{m}$ pore size) and washed several times with DW to remove residual salt and nonattached P(DOPA). Samples were dried under vacuum for $24 \mathrm{~h}$ at $35^{\circ} \mathrm{C}$. Deposition-precipitation method (Cu NPs surface modification): To attach $\mathrm{Cu}$ NPs, a deposition-precipitation procedure was employed. It was started by sonication of $0.2 \mathrm{~g}$ HAP/P(DOPA)2-15h modified samples in $14.42 \mathrm{~mL}$ of DW for 5 minutes. Then, $4.33 \mathrm{~mL}$ of $80 \mathrm{mM} \mathrm{Cu}\left(\mathrm{NO}_{3}\right)_{2} \cdot 3 \mathrm{H}_{2} \mathrm{O}$ was added to the solution followed by $\mathrm{pH}$ adjustment to 9 using $0.1 \mathrm{M}$ $\mathrm{NaOH}$. The reaction was kept under constant stirring $(200 \mathrm{rpm})$ for $2 \mathrm{~h}$ at $60^{\circ} \mathrm{C}$. Final HAP/P(DOPA)2-15h samples modified with $\mathrm{Cu}(\mathrm{OH})_{2}$ were vacuum filtered (nylon membranes with $0.45 \mu \mathrm{m}$ pore size) and washed several times with DW. Samples were dried under vacuum for $24 \mathrm{~h}$ at $35^{\circ} \mathrm{C}$. After drying, the samples were calcinated at $500^{\circ} \mathrm{C}$ under an inert Ar atmosphere for $4 \mathrm{~h}$ (the heating time was $2 \mathrm{~h}$ ).

Electrode preparation: Precursor solution for spray coating of the glassy carbon electrodes was prepared by sonicating $0.03 \mathrm{~g}$ of the photoelectroactive material in $0.6 \mathrm{~mL}$ of $5 \%$ Nafion solution and $0.6 \mathrm{~mL}$ of absolute ethanol for 20 minutes. Each glassy carbon electrode was spray-coated with $250 \mu \mathrm{L}(2 \times 100 \mu \mathrm{L}$ front and rear side and last $50 \mu \mathrm{L}$ for narrow sides $)$.

Photo/electrochemical analysis: Cyclic voltammetry (CV), chronoamperometry (CA), and linear sweep voltammetry (LSV), electrochemical surface area, and impedance measurements were performed by employing a two-compartment three-electrode electrochemical cell (homemade H-cell configuration). The two-compartment was divided using a cation exchange membrane (Nafion 117, Dupont) at room temperature and atmospheric pressure (please see Figure S13). In all electrochemical analysis, a saturated $\mathrm{Ag} / \mathrm{AgCl}$ reference electrode (RE) and a glassy carbon plate $(1 \times 1.5 \mathrm{~cm} \times 2 \mathrm{~mm})$ working electrode $(\mathrm{WE})$ coated with photo/electrocatalyst was used in the cathode chamber (Compartment 1$)$ and a Pt sheet $(1 \times 1$ $\mathrm{cm}$ ) employed as the counter electrode (CE) in the anode chamber (Compartment 2). 
Prior to electrolysis, the Nafion membrane was pretreated by heating in $\mathrm{H}_{2} \mathrm{O}_{2}$ aqueous solution (5.0 $\mathrm{wt} \%$ ) followed by $\mathrm{H}_{2} \mathrm{SO}_{4}(0.5 \mathrm{M})$ at $80{ }^{\circ} \mathrm{C}$ for $1 \mathrm{~h}$. Later boiled in distilled water for $1 \mathrm{~h}$ and then stored in ultrapure water. The electrolyte $\left(0.5 \mathrm{M} \mathrm{KHCO}_{3}, \mathrm{pH}=7.2\right)$ was saturated with high purity $\mathrm{CO}_{2}$ (flow rate, $20 \mathrm{sccm}$ ) before the analysis at least 2 hours. $20 \mathrm{ml}$ of $\mathrm{CO}_{2}$ saturated electrolyte was transferred into each compartment of the H-type electrochemical cell. The electrolyte was continuously purged $\left(\mathrm{CO}_{2}, 20 \mathrm{sccm}\right)$ during analysis.

All electrochemical measurements were carried out using a Metrohm workstation (Autolab, Netherlands) at room temperature. LSV measurements were performed with a scan rate of 50 $\mathrm{mV} \mathrm{s}^{-1}$ between $-0.6 \mathrm{~V}$ to $-2 \mathrm{~V}$ vs. $\mathrm{Ag} / \mathrm{AgCl}$ in $\mathrm{Ar} / \mathrm{CO}_{2}$-saturated $0.5 \mathrm{M} \mathrm{KHCO}_{3}$ solution. Electroanalysis (chronoamperometry) was performed by applying a constant potential ranging from $-0.6 \mathrm{~V}$ to $-2 \mathrm{~V} v s$. $\mathrm{Ag} / \mathrm{AgCl}$ and recording the current in $\mathrm{CO}_{2}$-saturated $0.5 \mathrm{M} \mathrm{KHCO}_{3}$ electrolyte for 2500 seconds. iR drop is compensated via positive feedback correction at $85 \%$ of estimated $\mathrm{R}_{\mathrm{u}}$ obtained by electrochemical impedance spectroscopy (EIS) measurement $\begin{array}{lllll}\text { following } & \text { Jaramillo } & \text { et } & & \\ & & \text { work }\end{array}$ (http://www.rsc.org/suppdata/ee/c2/c2ee21234j/c2ee21234j.pdf).

For photoelectrochemical analysis, light irradiation was performed using a 300W Xe lamp solar simulator (ToptionLab). The long-term $\mathrm{ERCO}_{2}$ experiments were performed for all photo/electrocatalysts to evaluate the durability.

Electrochemical capacitance measurements for estimating the electrochemical active surface area (ESCA) of catalysts have been performed using cyclic voltammetry. As-prepared photo/electrocatalysts were tested with scan rates varying from 10 to $150 \mathrm{mV} \mathrm{s}^{-1}$ with an interval of 10 to $20 \mathrm{mV} \mathrm{s}^{-1}$ at the potential range of $0.1 \mathrm{~V}$ to $0.2 \mathrm{VRHE}$. The electrochemical double-layer capacitance $\left(\mathrm{C}_{\mathrm{dl}}\right)$ was calculated by plotting Ja-Jc against the scan rate, where the slope was twice that of $\mathrm{C}_{\mathrm{dl}}$. 
X-ray powder diffraction (XRD): XRD tests were carried out using a Bruker D8 Advance. A $\mathrm{HAP}, \mathrm{HAP} / \mathrm{CuO}$, and $\mathrm{HAP} / \mathrm{P}(\mathrm{DOPA}) 15 \mathrm{~h} / \mathrm{Cu}$ powder was placed in the specimen holder and pressed on a glass slide. The XRD spectra were obtained by running three repeats at 2-theta from $5^{\circ}$ to $90^{\circ}$ with a step of $0.02^{\circ}$ and a dwell time of 0.5 seconds. A silicon wafer was used to calibrate the instrument.

X-ray photoelectron spectroscopy (XPS): High-resolution XPS was performed with a SPECS spectrometer using an XR 50 MF monochromatic X-ray radiation source $(1486.7 \mathrm{eV})$ and a Phoibos 150 2D CCD hemispherical analyzer and detector. The pressure inside the chamber during the experiments was set to $5 \times 10^{-10}$ mbar or lower. Wide-scan surveys were obtained at $E p=80 \mathrm{eV}$, with subsequent high-resolution scans of the desired core lines carried out at $\mathrm{Ep}=50$ $\mathrm{eV}$ with an acquisition step of $0.1 \mathrm{eV}$. The samples were placed on double-sided carbon tape. The binding energy values were referenced to the adventitious carbon peak at $285 \mathrm{eV}$.

Scanning electron microscopy (SEM)/ Energy-dispersive X-ray spectroscopy (EDX): SEM coupled with EDX was employed to perform surface morphology characterization and elemental mapping analysis. Electron microscopy was also conducted on Maia 3 and Lyra 3 (Tescan) in STEM mode for better material contrast.

Transmission electron microscopy (TEM): TEM was performed using EFTEM Jeol 2200 FS microscope.

Fourier-transform infrared spectroscopy (FTIR): ATR-FTIR measurements were performed on a Nicolet iS50R FTIR spectrometer (Thermo Scientific) and used to determine the characteristic functional groups.

Raman spectra were obtained using a LabRam confocal micro-Raman spectroscope (Horiba Scientific) in backscattering geometry with a CCD detector, $514 \mathrm{~nm} \mathrm{Ar} \mathrm{laser,} \mathrm{and} \mathrm{10x}$ objective. 
$U V$-Vis measurements were performed using a Lambda 850+ spectrophotometer (Parkin Elmer). All sample in the same concentrations were first well dispersed in destile water using sonication bath then UV-Vis measurement in spectrometric quivetes has been performed.

Thermogravimetric analysis (TGA): TGA measurements were performed in $\mathrm{Ar} / \mathrm{O}_{2}(4: 1)$ atmosphere with $10^{\circ} \mathrm{C} / \mathrm{min}$ heating rate from room temperature to $900^{\circ} \mathrm{C}$.

Product analysis: The gas-phase products were analyzed by a gas chromatograph (Agilent) system equipped with FID, TCD, and Mass Spectrometer. Gas products have been collected in sampling bags during electrolysis and sent for analysis at the end of electrolysis. The liquid products also were analyzed using a high-performance liquid chromatography-mass spectroscopy (HPLC-MS, TSQ Quantum Access Max-triple quadrupole, Thermo Scientific) after completing the electrolysis process.

ICP-OES analysis: ICP-OES measurements were performed using a Spectro ARCOS (SPECTRO Analytical Instruments). The spectrometer employed the Paschen-Runge configuration with an optimized Rowland circle polychromator, measuring simultaneously in the broad spectral range of 130-770 nm using 32 linear CCD detectors. The detection limits for the determined elements are at ppb (by mass) levels. For final composite samples, a decomposition procedure was used named Schöniger oxidation. ${ }^{2}$ A precisely weighed sample of $5 \mathrm{mg}$ was wrapped in an ash-free nitrocellulose paper and burned in a flask (filled with pure oxygen) with Pt sample holder. The burning products were decomposed by prolonged ultrasonication and heating with ICP-grade nitric acid. After this procedure, the resultant sample solutions were diluted with deionized water $(\mathrm{R}=18.2 \mathrm{M} \Omega)$ to obtain a concentration of nitric acid of around $1 \%$ and used for analysis. Blank experiments were performed with ashfree cellulose paper to subtract the amount of impurities introduced by sample preparation. The calibration of the spectrometer was performed with certified ICP-OES elements standards in 
$2 \%(\mathrm{wt} / \mathrm{wt}) \mathrm{HNO}_{3}$ and $2 \%(\mathrm{wt} / \mathrm{wt}) \mathrm{HNO}_{3}-2 \%(\mathrm{wt} / \mathrm{wt}) \mathrm{HCl}$ matrixes; $\mathrm{Y}$ was used as an internal standard.

BET analysis $\left(\mathrm{N}_{2}\right)$ : BET analysis (N2): $\mathrm{N} 2$ absorption isotherms were measured at $77 \mathrm{~K}$ using a Beckman Coulter SA3100 to determine the BET area and characterize the pore size distribution of materials. The samples were first activated at $150 \mathrm{oC}$ for $4 \mathrm{~h}$ under dynamic vacuum before gas sorption measurement, and N2 were used as the absorbate.

Calculations: For all calculations, the potential recorded by saturated $\mathrm{Ag} / \mathrm{AgCl}$ has been converted to the RHE scale using the following Equation (1):

$E(v s R H E)=E_{A g / A g C l}+E_{A g / A g C l}^{0}+0.059 \times p H$

where $E_{A g / A g C l}^{0}=0.1989 \mathrm{~V}$ vs $R H E$

The Faradaic efficiency (FE) of the $\mathrm{CO}_{2}$ electrochemical reduction of products was calculated using the following formula:

$F E=\frac{n_{x} \times F \times N_{x}}{i \times t} \times 100 \%$

Where $x$ is the product, $n$ is the number of electrons, $F$ is the Faraday constant, $N$ is the moles of produced $x, t$ is the time, and $i$ is the current. 


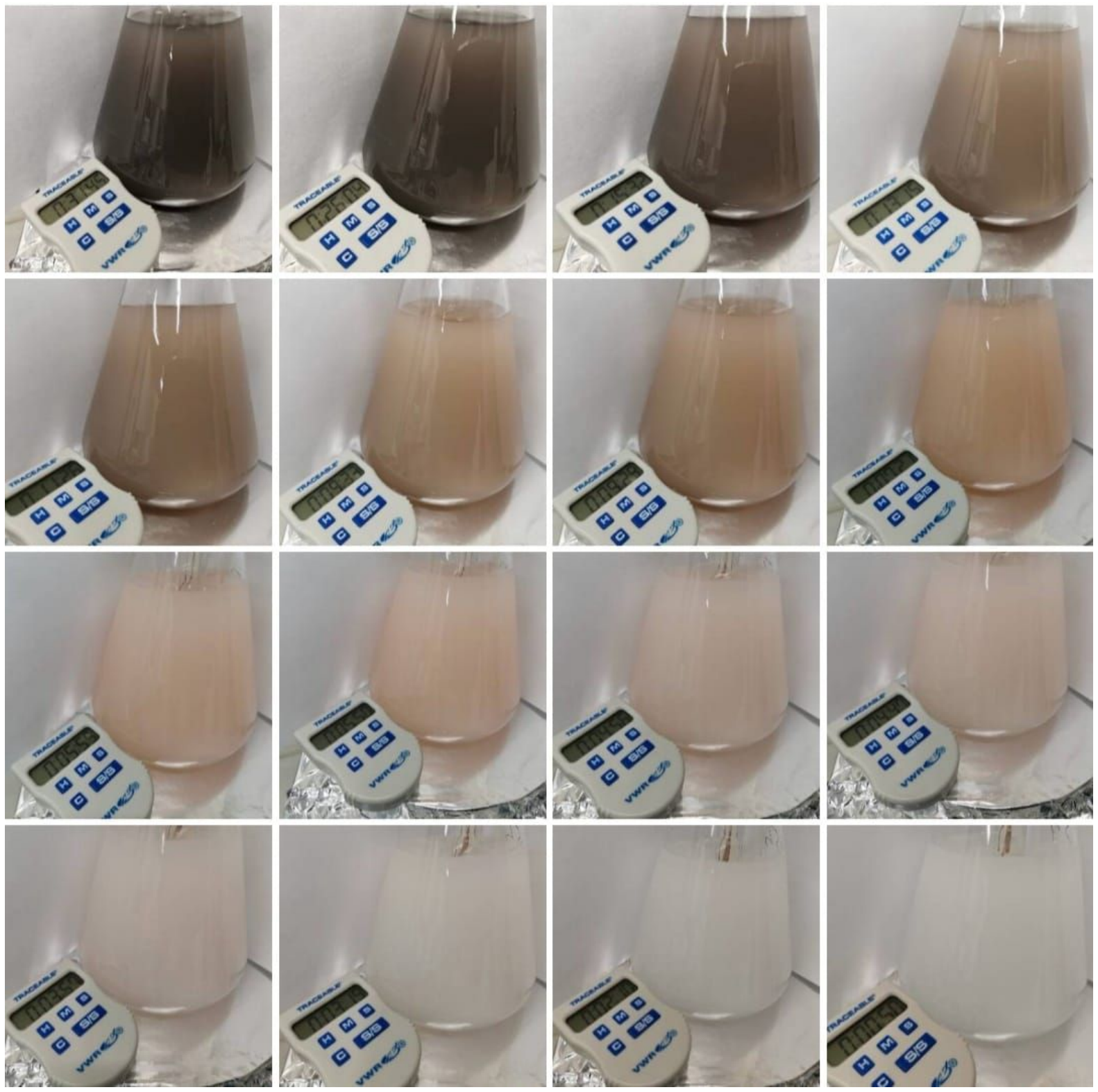

Figure S1. Polymerization starts rapidly in minutes, followed by fast color change of the solution. 
A

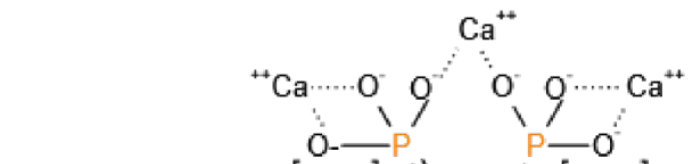

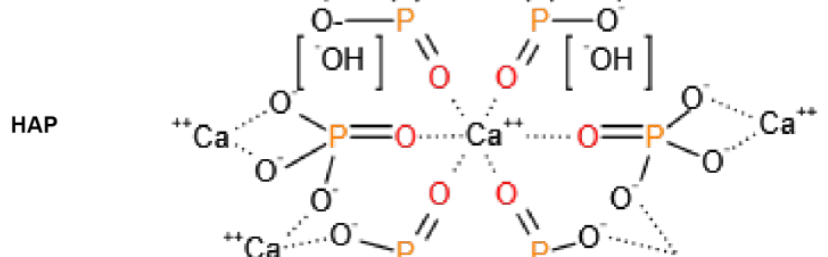

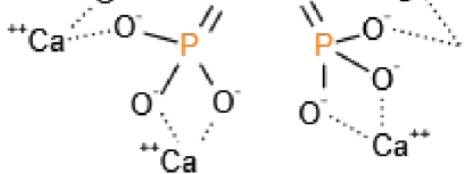

B

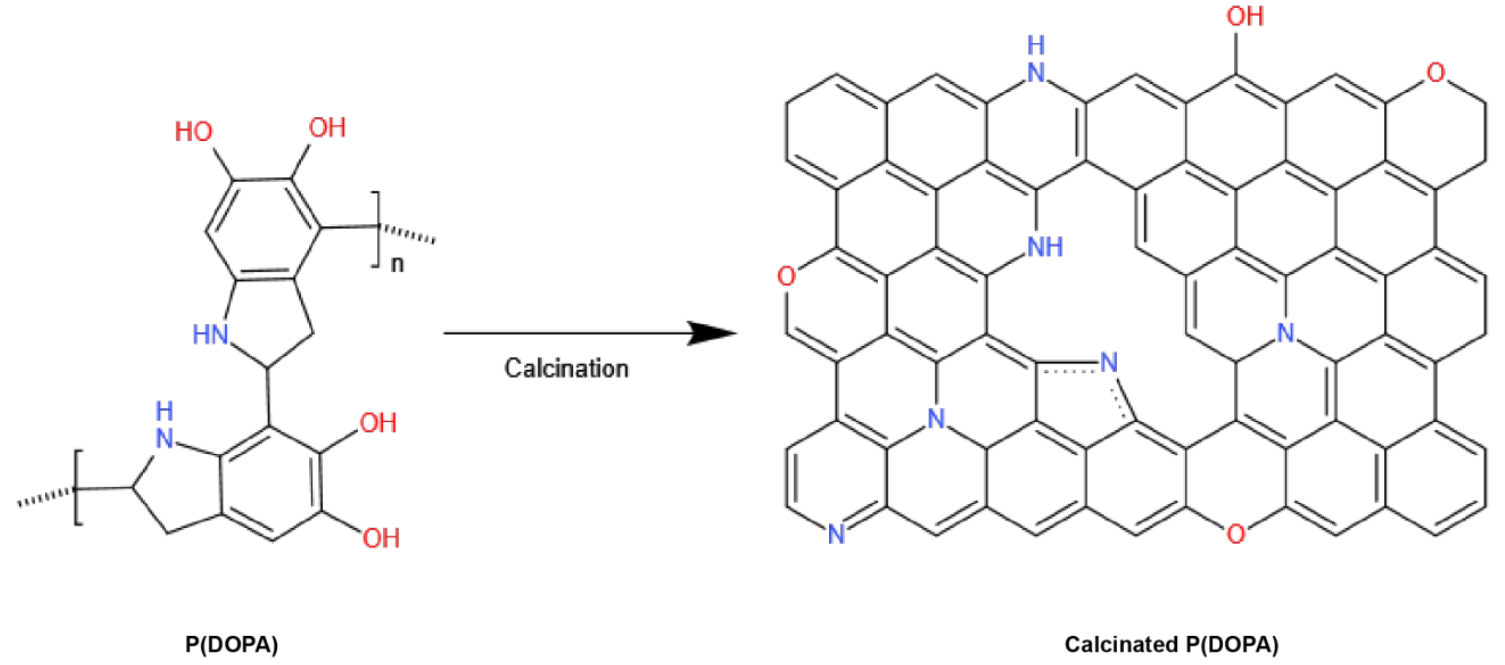

Figure S2. Structure of A) HAP and B) P(DOPA) before and after calcination. ${ }^{34}$ 

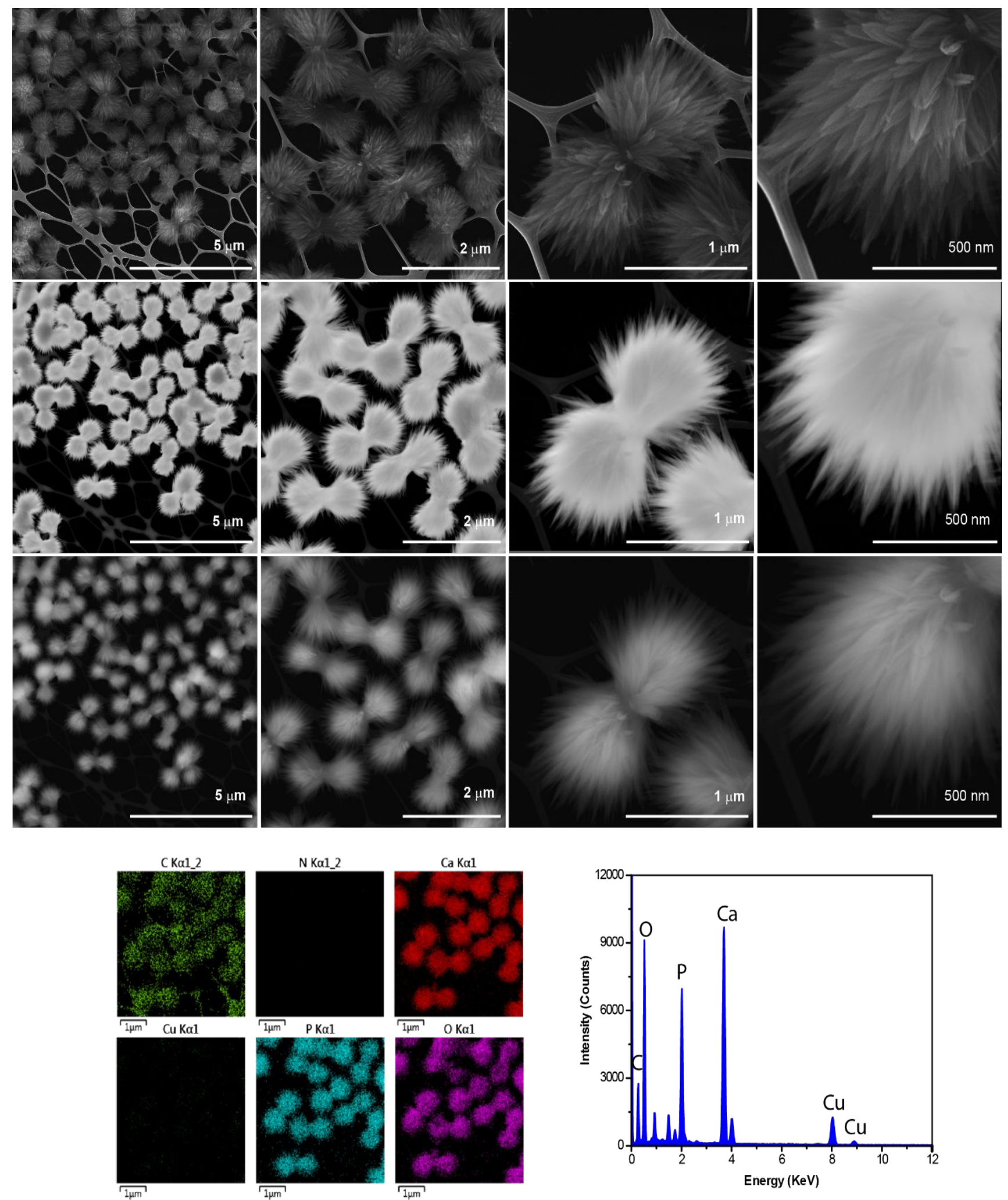

Figure S3. SEM, STEM-DF and STEM-HADF images with EDX elemental mapping and EDX spectra of the HAP core material. 

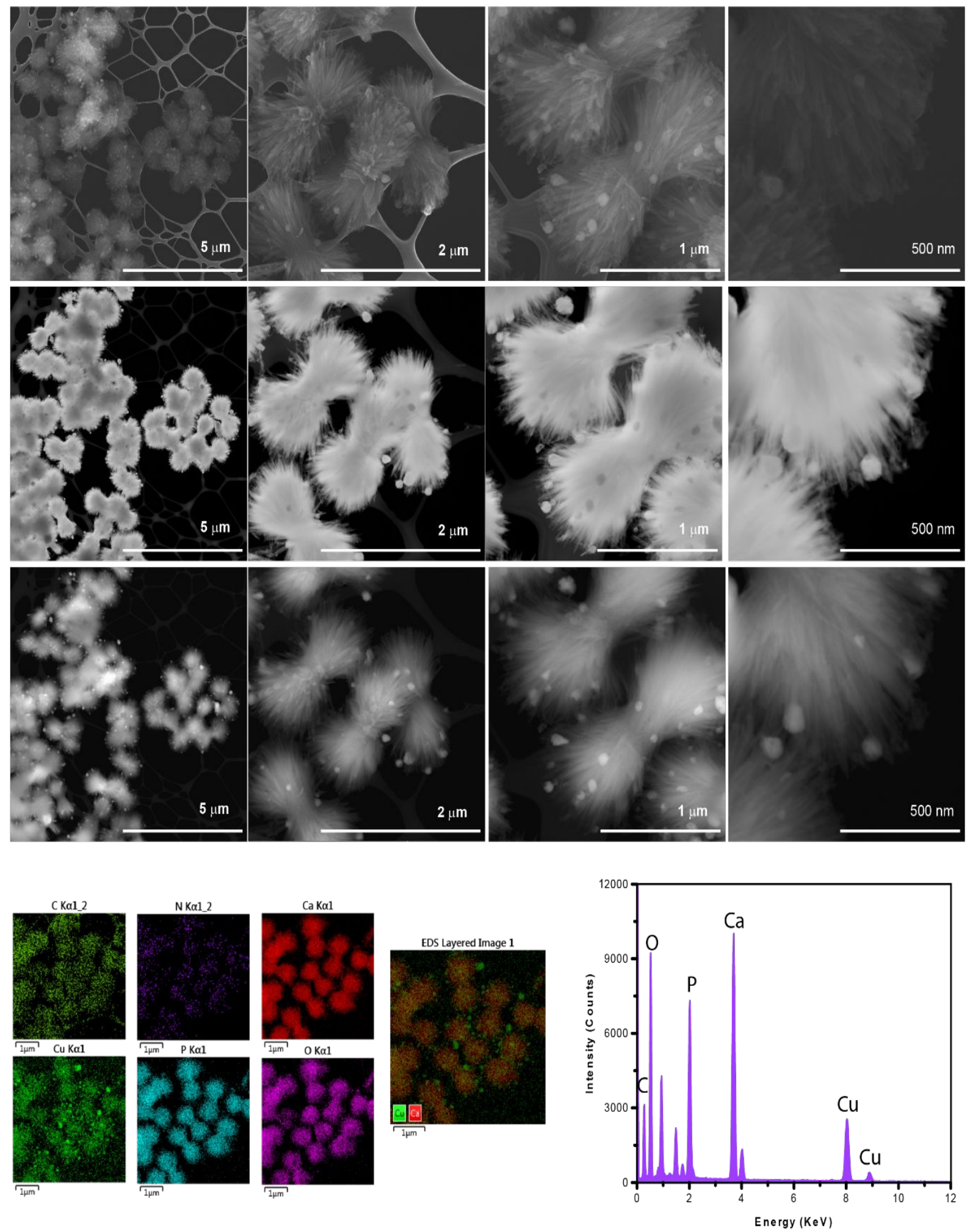

Figure S4. SEM, STEM-DF and STEM-HADF images with EDX elemental mapping and EDX spectra of the HAP/P(DOPA) $2 \mathrm{~h} / \mathrm{Cu}$ composite. 

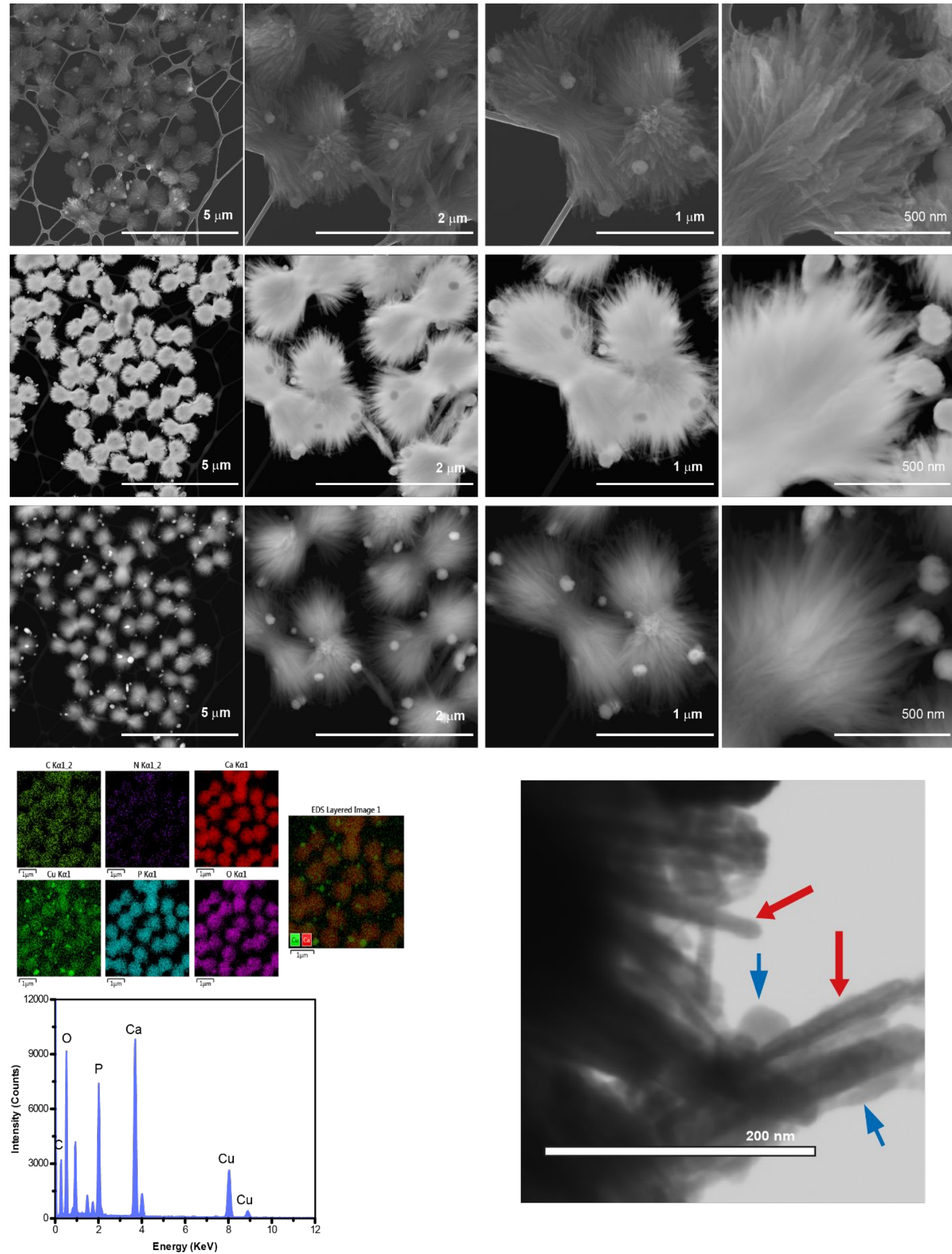

Figure S5. SEM, STEM-DF and STEM-HADF images with EDX elemental mapping and EDX spectra of the HAP/P(DOPA) $5 \mathrm{~h} / \mathrm{Cu}$ composite. 

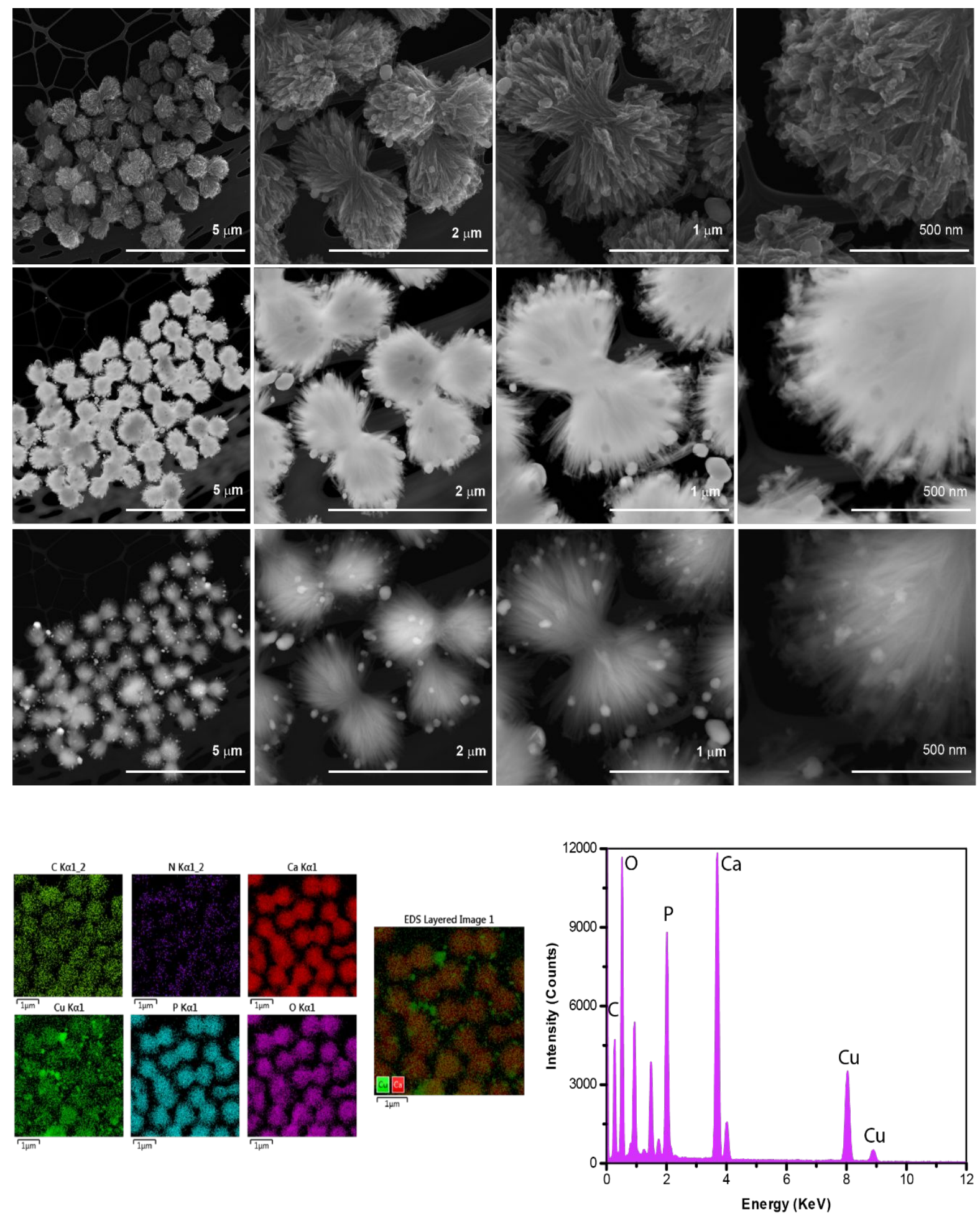

Figure S6. SEM, STEM-DF and STEM-HADF images with EDX elemental mapping and EDX spectra of the HAP/P(DOPA) $15 \mathrm{~h} / \mathrm{Cu}$ composite. 


\section{HRTEM images and SAED}

HRTEM image of the basic HAP core (Figure S7A) clearly shows the needle-like structured crystals aggregated together, enhancing the reactive surface area for absorption and activation of the $\mathrm{CO}_{2}$ molecules. Small needles in HAP structure are in the range of 10-20 $\mathrm{nm}$ in diameter. As it can be seen in (Figure S7B), the coated P(DOPA) layer on HAP (HAP/P(DOPA)15h, 15h of the polymerization procedure) is highly homogeneous. The thickness of the polymer coating layer after 15 hours of polymerization is estimated $\sim 10 \mathrm{~nm}$ with local spherical projections up to $30 \mathrm{~nm}$. Figure $\mathbf{S 7 C}$ presents the precipitated $\mathrm{Cu}$ nanoparticles attached to the surface of

\section{HAP/P(DOPA).}

It is noteworthy to point out that a significant difference has been shown between the various phases in the final composite material (Figure S7D, left panel: HAP, Middle panel: $\mathrm{HAP} / \mathrm{P}(\mathrm{DOPA})$ and right panel: $\mathrm{HAP} / \mathrm{P}(\mathrm{DOPA}) 15 / \mathrm{Cu})$ by electron diffraction techniques (SAED). As Figure S7D presents in the left panel corresponding to the HAP core, traces of preferential orientation of the needle-like crystals in one axis can be observed together with forming a highly polycrystalline pattern. The middle panel corresponding to the $\mathrm{P}(\mathrm{DOPA}) / \mathrm{HAP}$ shows a significant increase in the proportion of the amorphous phase of the particle. This observation is in agreement with the fact that the thickness of the coated polymer 
$(\mathrm{P}(\mathrm{DOPA}))$ reaches a greater width than the HAP needles alone after 15 hours of polymerization. The right panel in Figure S7D (HAP/P(DOPA)15/Cu) presents the beam focused primarily on the precipitated $\mathrm{Cu}$ nanoparticles and the dominant monocrystalline cubic pattern of the $\mathrm{Cu}$.

A

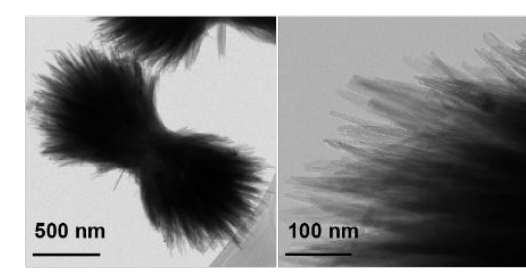

C
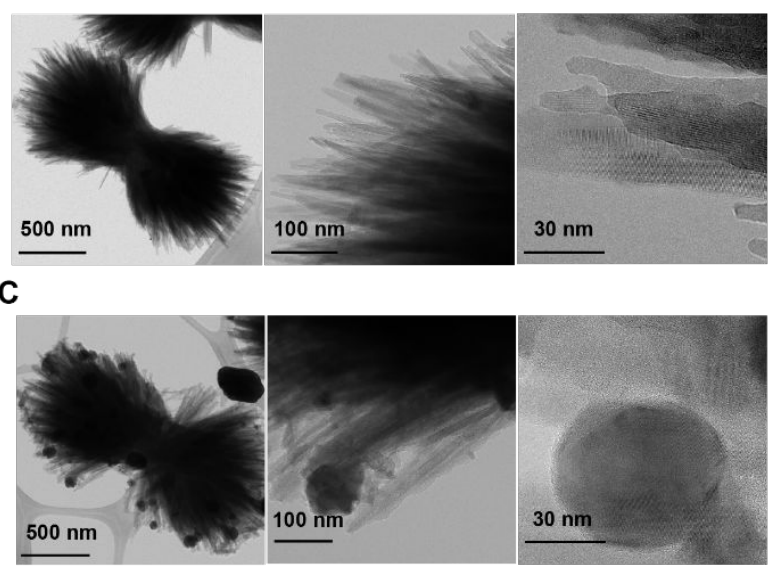

B

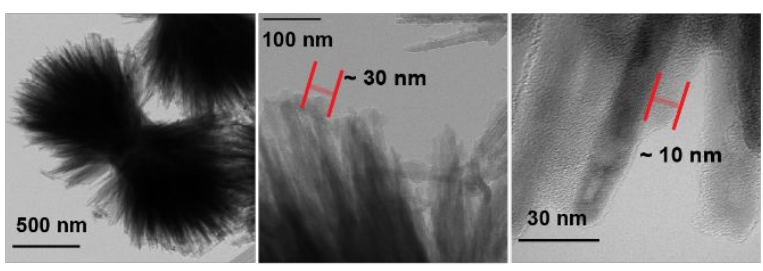

D
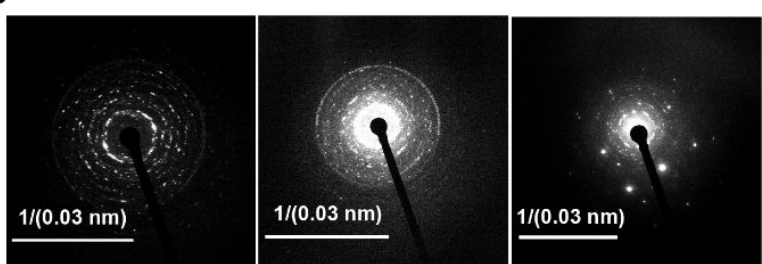

Figure S7. HRTEM images of the A) HAP core; B) HAP core with functional P(DOPA)

coating; C) HAP core modified with P(DOPA) and Cu NPs (HAP/P(DOPA)15h); D) Selected area electron diffraction (SAED) pattern of HAP, HAP/P(DOPA) and HAP/P(DOPA)15h/Cu. 


\section{Raman and FTIR analysis}

The changes of the structural and chemical composition of the samples have been monitored using Raman and FTIR spectroscopy in all steps of the synthesis procedure from the HAP core to $\mathrm{HAP} / \mathrm{P}(\mathrm{DOPA})$ and $\mathrm{HAP} / \mathrm{P}(\mathrm{DOPA}) / \mathrm{Cu}$ modified particles (Figures S7). The Raman spectrum of the HAP core presents all significant bands characteristic for this hexagonal crystal. The symmetric stretching mode of phosphate ion, which is the characteristic peak of HAP, appeared at $963 \mathrm{~cm}^{-1}$ as a sharp and intensive peak. Another peak positioned at 1049 $\mathrm{cm}^{-1}$ belongs to the antisymmetric vibration state of the $\mathrm{PO}_{4}{ }^{3-}$ ion. Vibration at $1078 \mathrm{~cm}^{-1}$ corresponds primarily to $\mathrm{C}-\mathrm{O}$ stretching and $\mathrm{CH}_{2}$ rocking vibrations. The observed vibration at $3574 \mathrm{~cm}^{-1}$ and $2929 \mathrm{~cm}^{-1}$ (see Figure S7.A inset) belongs to $-\mathrm{OH}$ stretching and $-\mathrm{CH}_{2}-$ bounds, respectively. The symmetric bending modes for $\mathrm{PO}_{4}{ }^{3-}$ are presented at 450 and 432 $\mathrm{cm}^{-1}$. The other antisymmetric bending modes of phosphate ions are presented at 611,581 , and $594 \mathrm{~cm}^{-1}$. This result represents the possibility of pure microcrystal synthesis with citric acid residuals as a stabilizing agent, facilitating dispersion in aqueous solutions in further stages of synthesis. ${ }^{5}$ After coating the crystals with P(DOPA) (polymerization procedure), some changes occur. Dominant vibration of the $\mathrm{PO}_{4}{ }^{3-}$ ion at $950 \mathrm{~cm}^{-1}$ is slightly shifted according to the interaction with the $\mathrm{P}(\mathrm{DOPA})$ layer, and all other vibration states are in a strong overlay. Figure 
S7(B-C) presents the FTIR analysis of the final HAP/P(DOPA) $15 \mathrm{~h} / \mathrm{Cu}$ composite. The broadband located at $3500-2500 \mathrm{~cm}^{-1}$ is assigned to the $v(\mathrm{O}-\mathrm{H})$ and $v(\mathrm{~N}-\mathrm{H})$ stretching modes.

The peaks present at 1578,1454 , and $1413 \mathrm{~cm}^{-1}$ derived from the aromatic ring in the polymer. ${ }^{6-}$

${ }^{7}$ Residual positions at $1022,632,601$, and $561 \mathrm{~cm}^{-1}$ belong to the $\mathrm{PO}_{4}{ }^{3-}$ groups. ${ }^{8}$

A

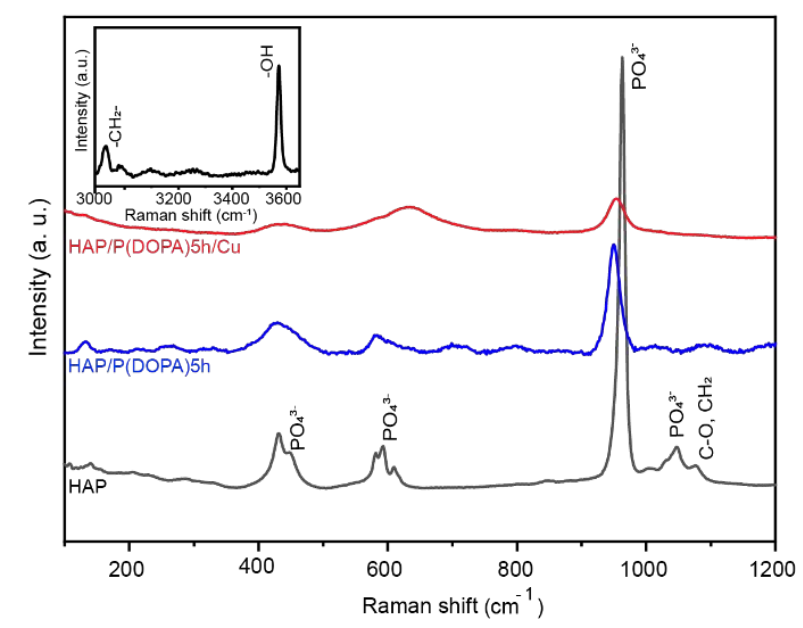

B
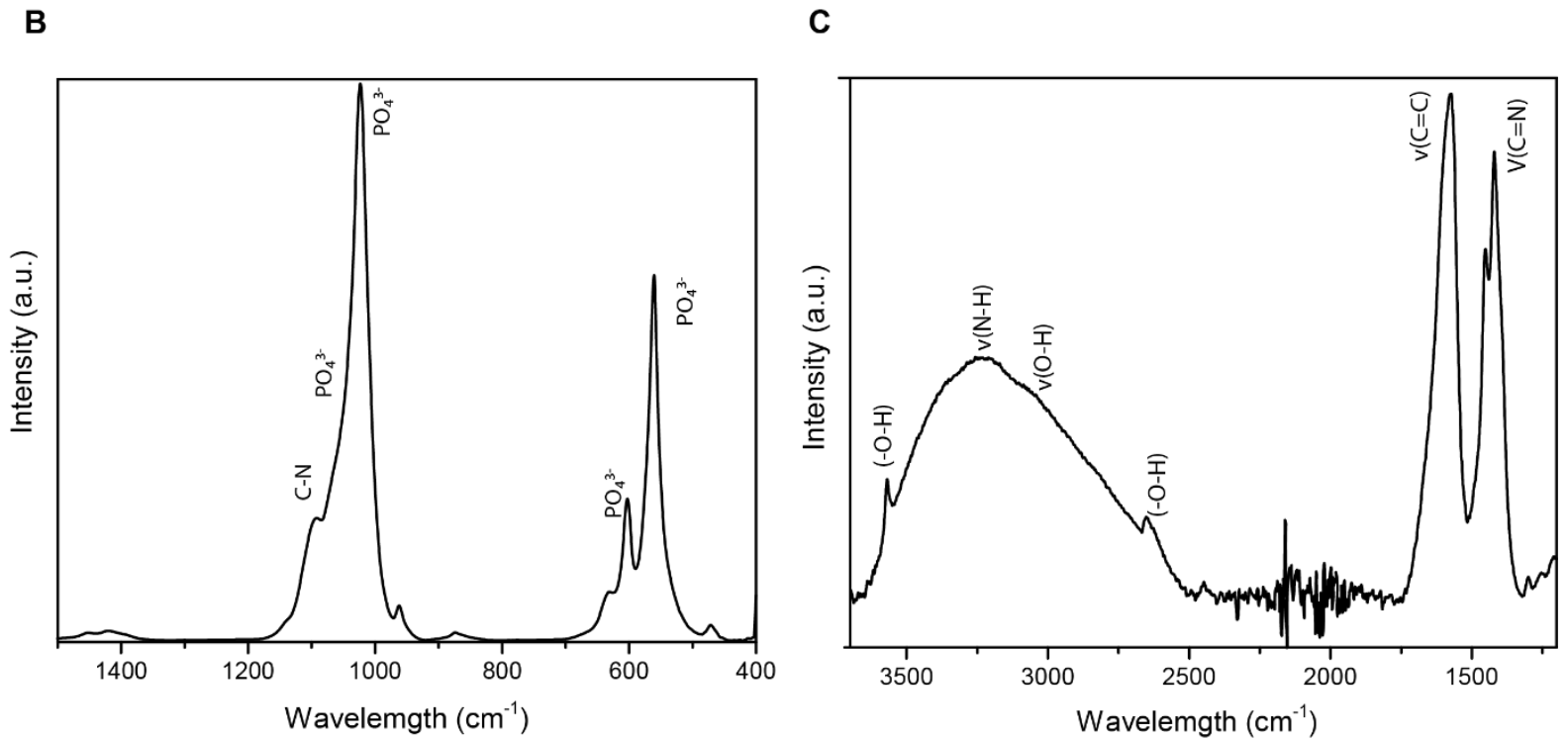

Figure S8. A) Raman spectra of the HAP cores, HAP/P(DOPA) $5 \mathrm{~h}$ and HAP/P(DOPA) $5 \mathrm{~h} / \mathrm{Cu}$ modified samples, B and C) FTIR analysis of the final HAP/P(DOPA) $15 \mathrm{~h} / \mathrm{Cu}$ composite 

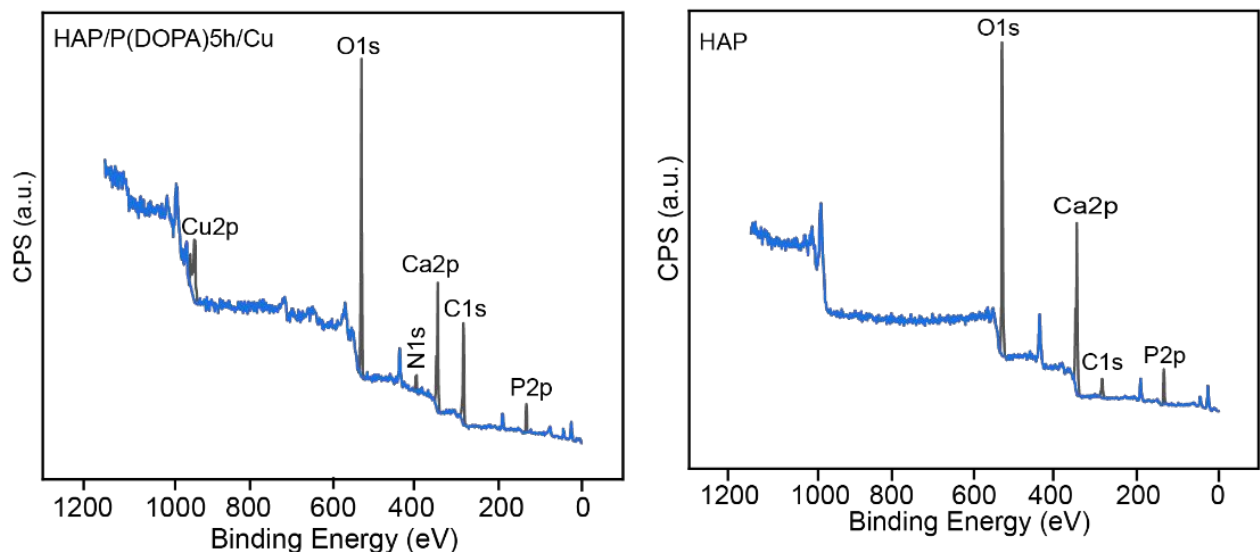

B
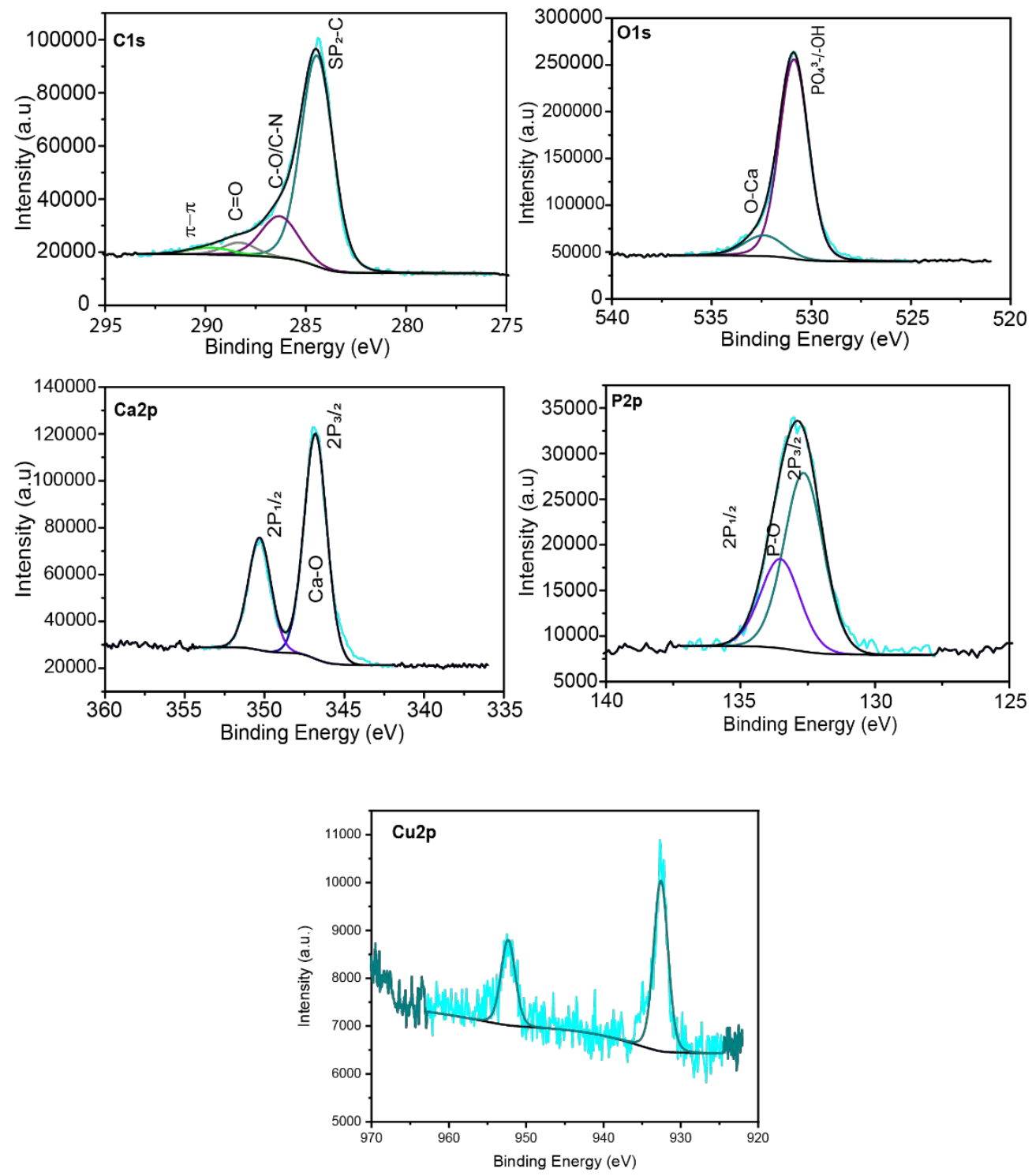

Figure S9 A) XPS raw spectra of the HAP and HAP/P(DOPA) $5 \mathrm{~h} / \mathrm{Cu}, \mathrm{B})$ XPS study of final $\mathrm{HAP} / \mathrm{P}(\mathrm{DOPA}) 5 \mathrm{~h} / \mathrm{Cu}$ composite surface chemistry $(\mathrm{C} 1 \mathrm{~s}, \mathrm{O} 1 \mathrm{~s}, \mathrm{Ca} 2 \mathrm{p}, \mathrm{P} 2 \mathrm{p})$ areas with corresponding high-resolution $\mathrm{Cu} 2 \mathrm{p}$ area. 

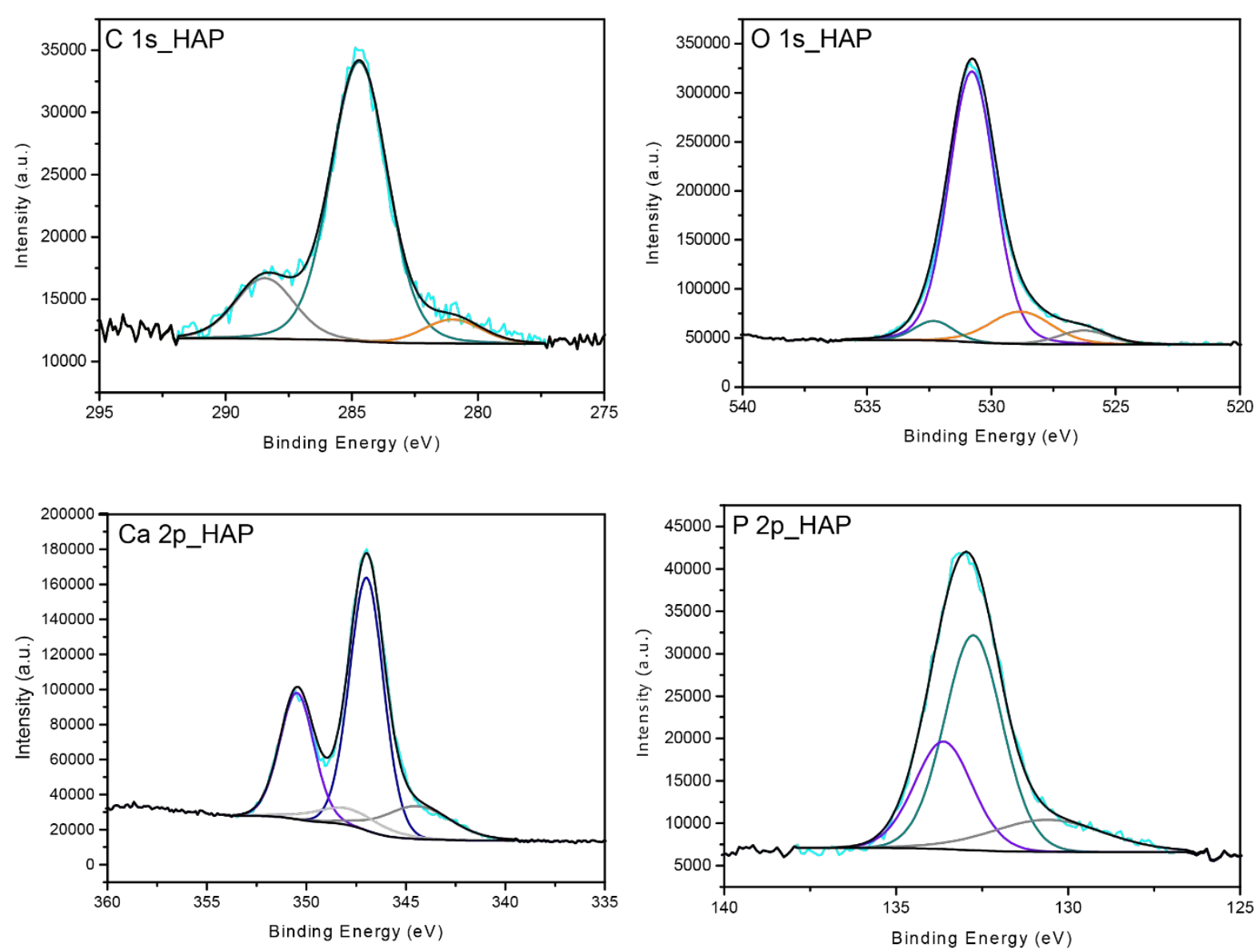

Figure S10. XPS evaluation of the $\mathrm{C} 1 \mathrm{~s}, \mathrm{O} 1 \mathrm{~s}, \mathrm{Ca} 2 \mathrm{p}$ and $\mathrm{P} 2 \mathrm{p}$ spectra of the pure HAP core. 

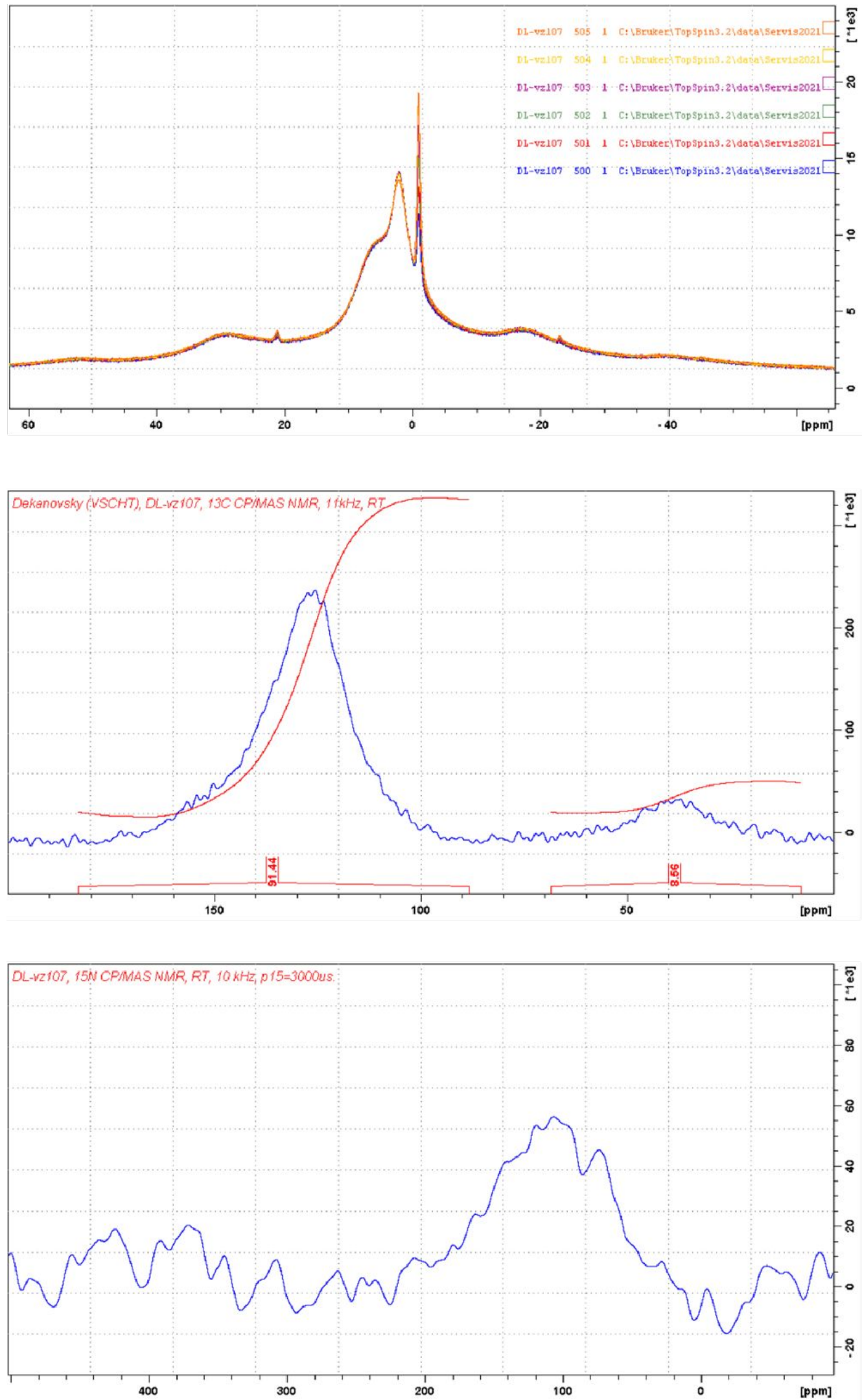

Figure S11. ssNMR analysis of the final HAP/P(DOPA) $15 \mathrm{~h} / \mathrm{Cu}$ composite for ${ }^{1} \mathrm{H},{ }^{13} \mathrm{C}$ and ${ }^{15} \mathrm{~N}$. 


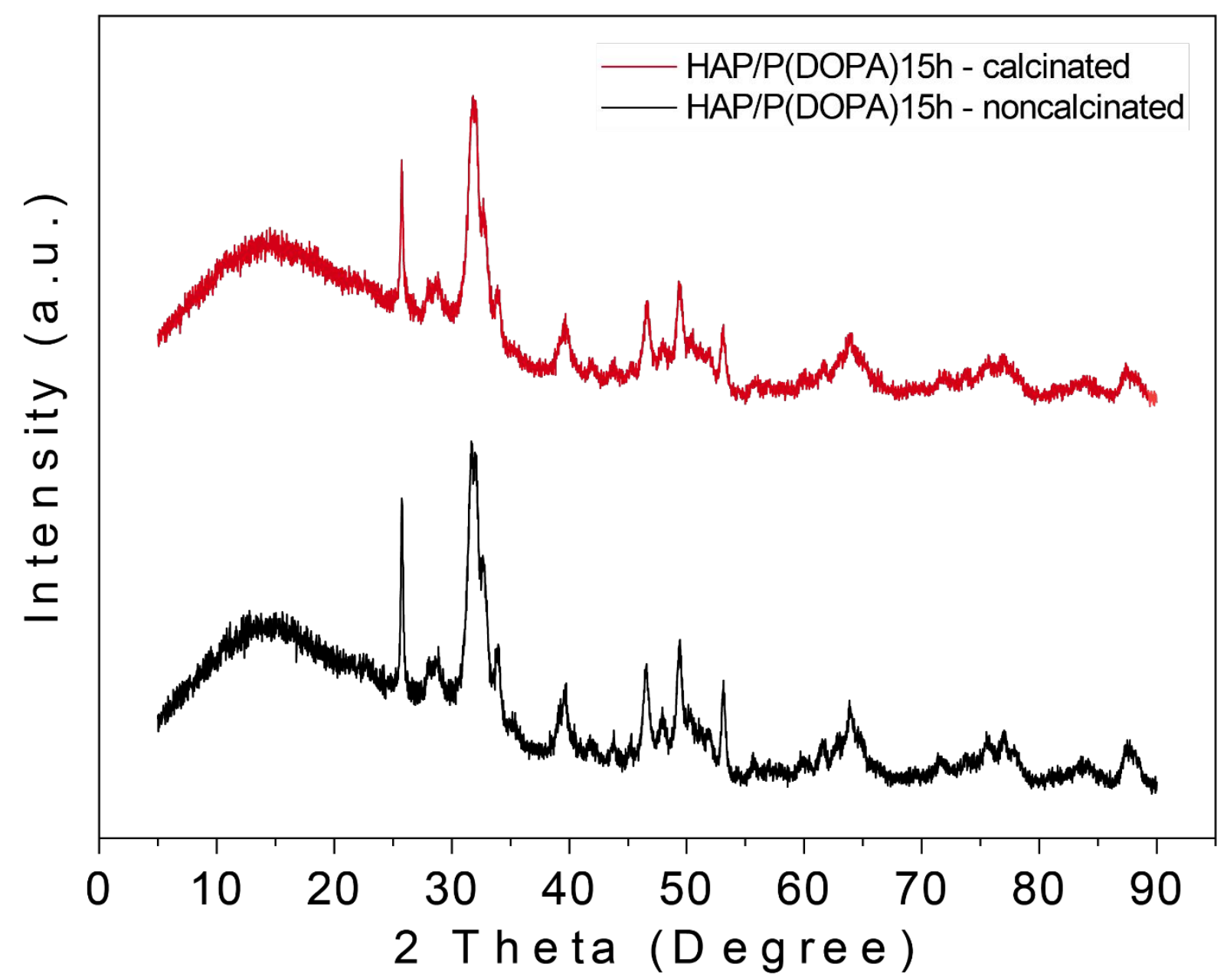

Figure S12. XRD comparison of the calcinated and noncalcinated HAP/P(DOPA)15h sample. 

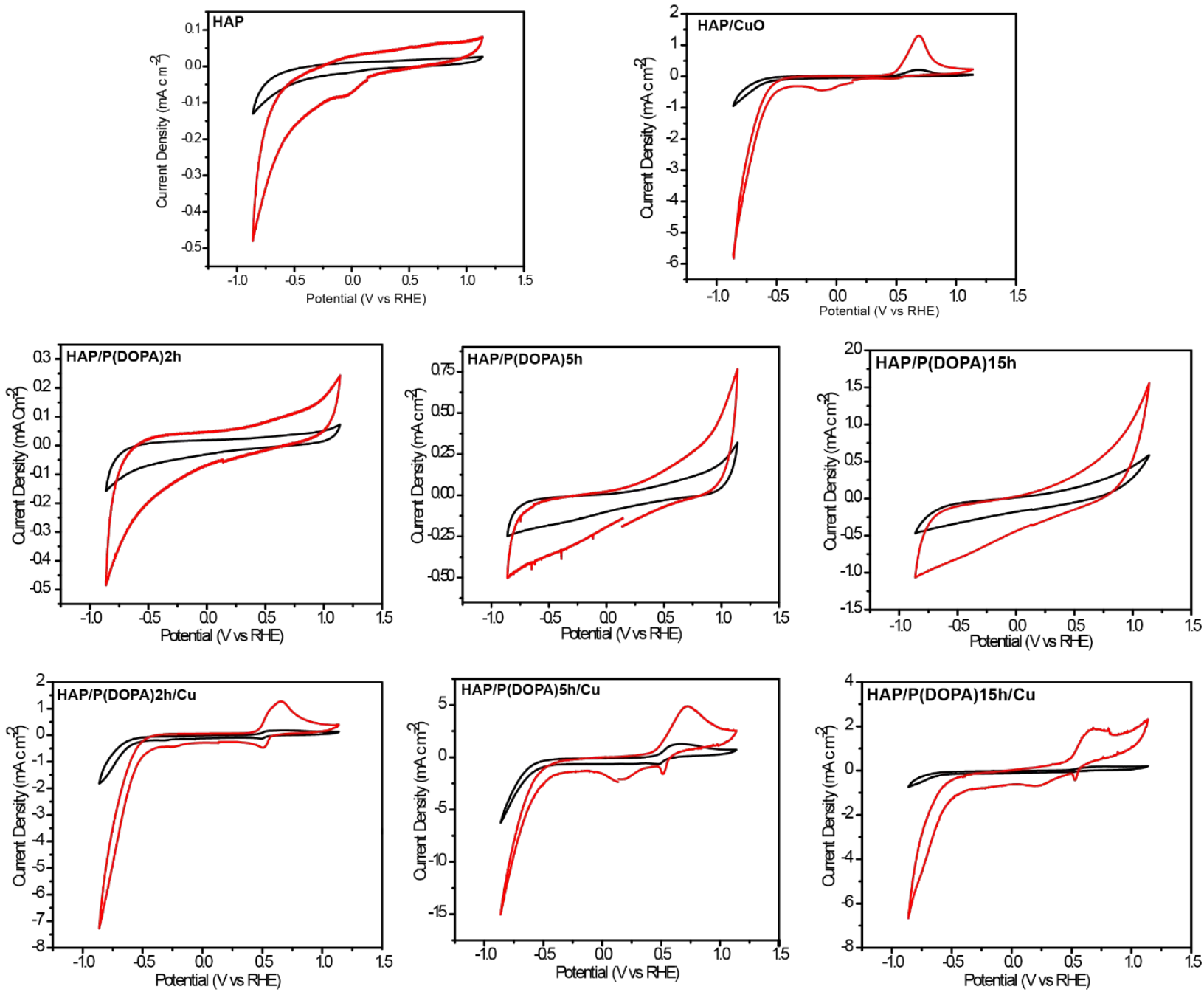

Figure S13. Cyclic voltammetry (CV) curves at various scan rates $\left(50 \mathrm{mV} \mathrm{s}^{-1}\right)$ for all samples (including blanks) in both EC (black) and PEC (red) analysis modes. 
A

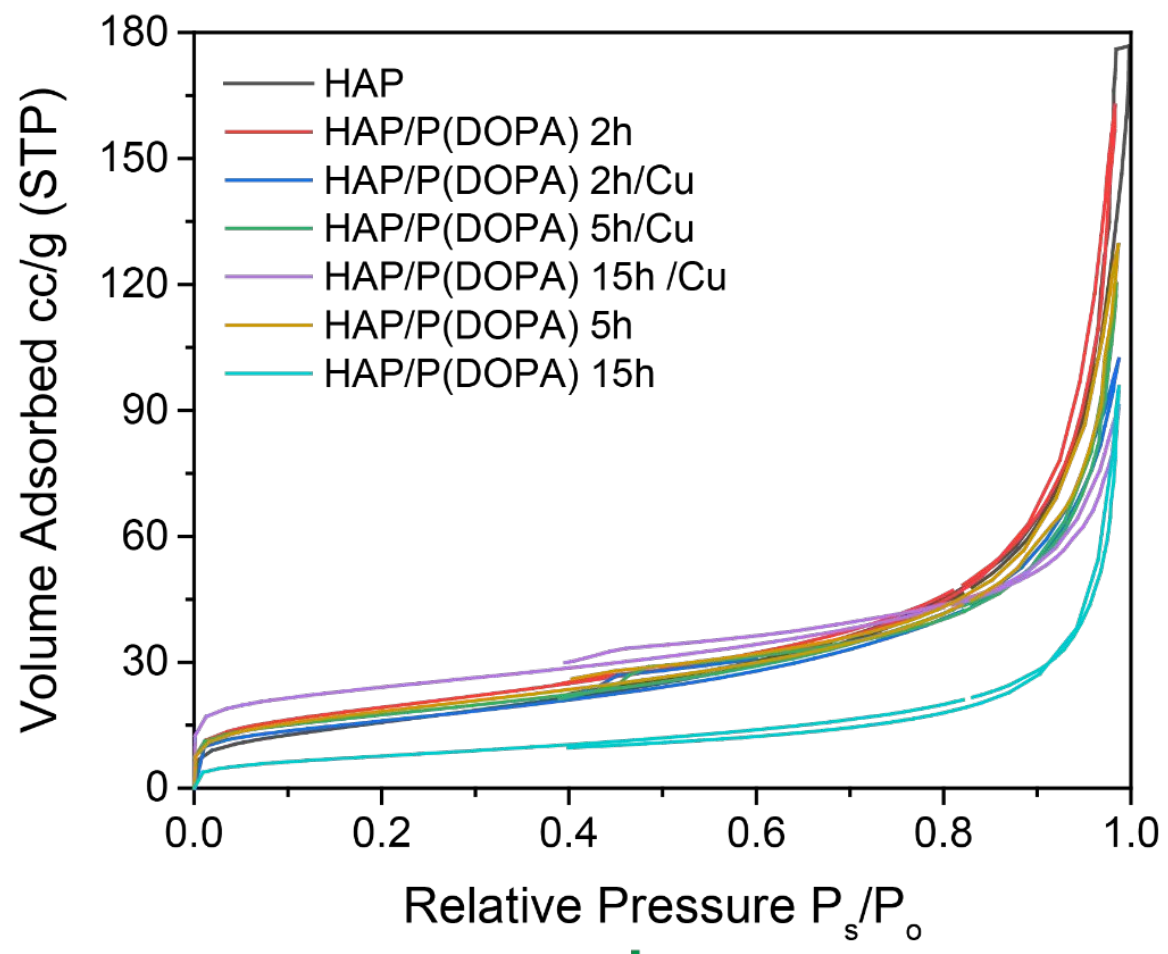

B

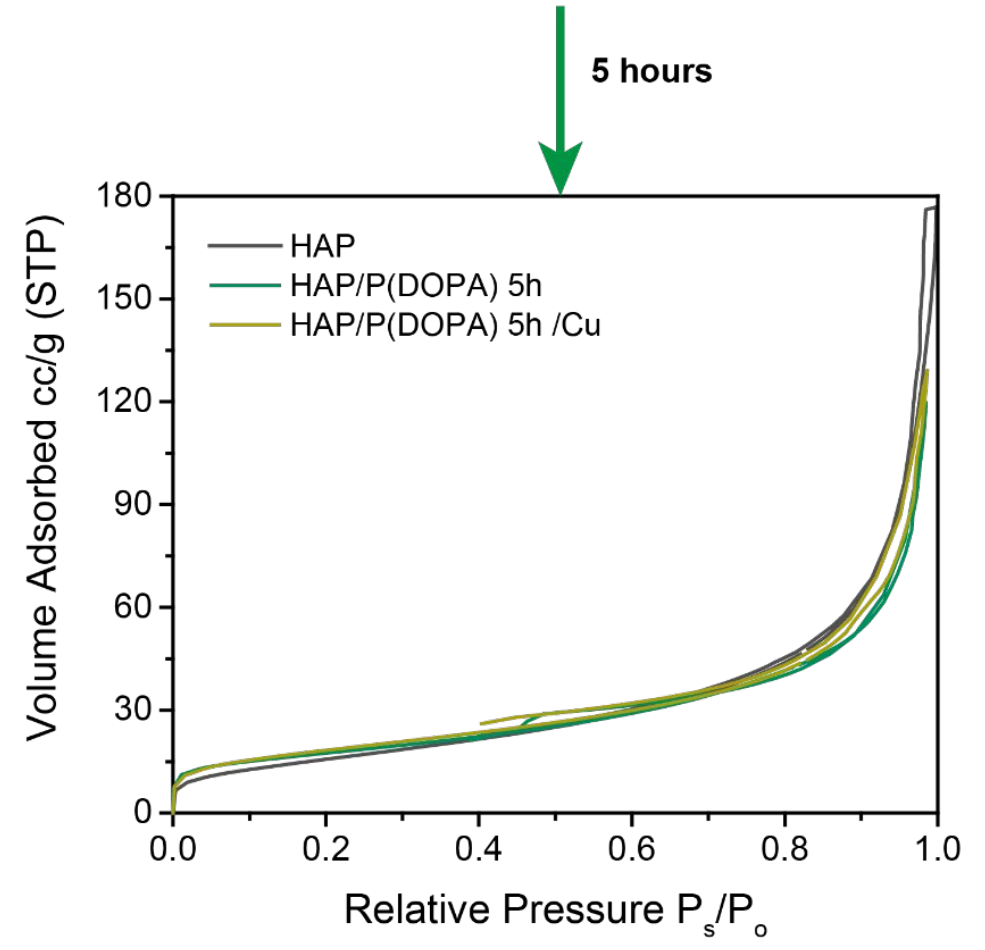

Figure S14. A) BET of the catalyst's and B) the most efficient derivates 


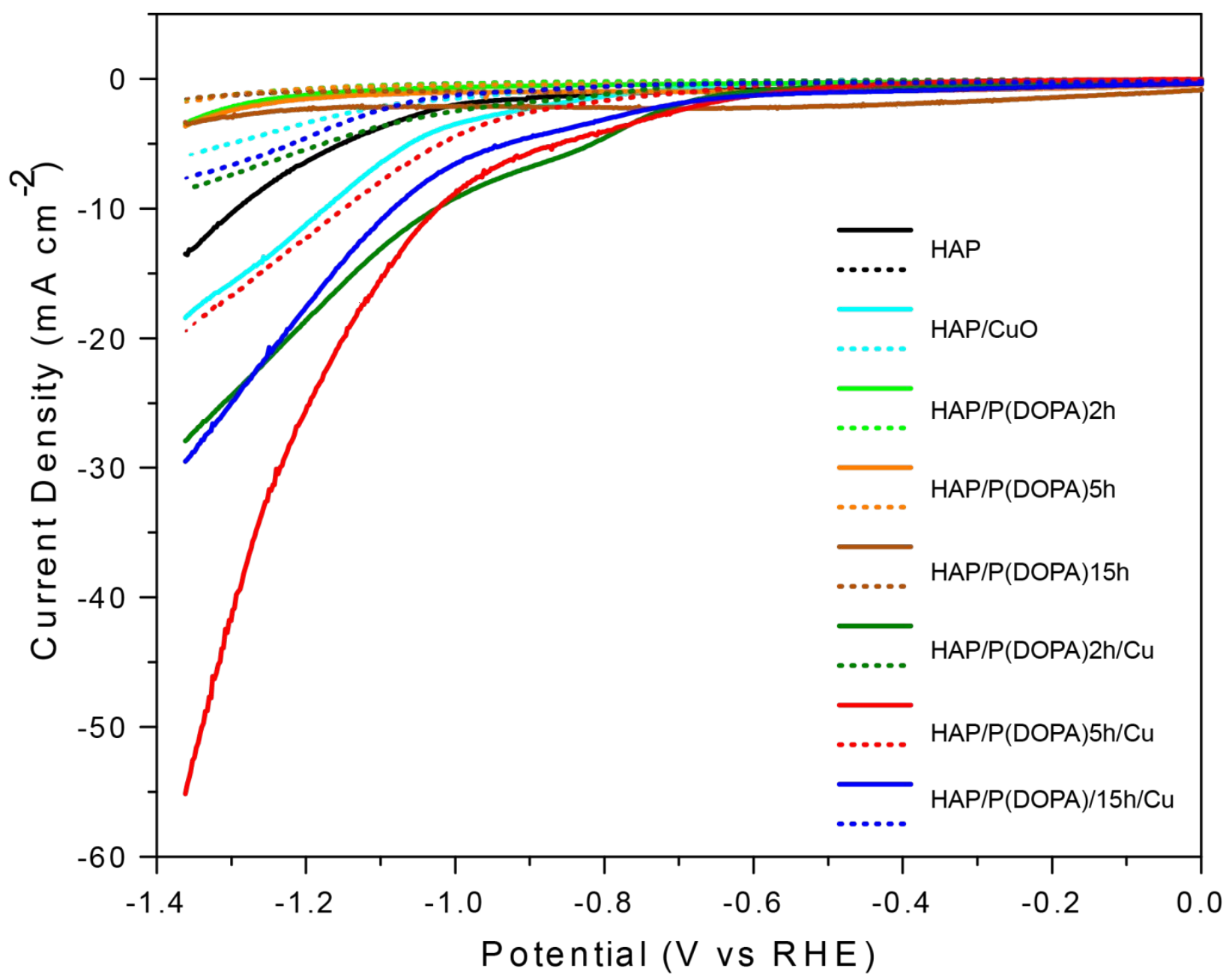

Figure S15. Linear sweep voltammogram of all samples (including blanks) in $\mathrm{CO}_{2}$-saturated $0.5 \mathrm{M} \mathrm{KHCO}_{3}$. 
A

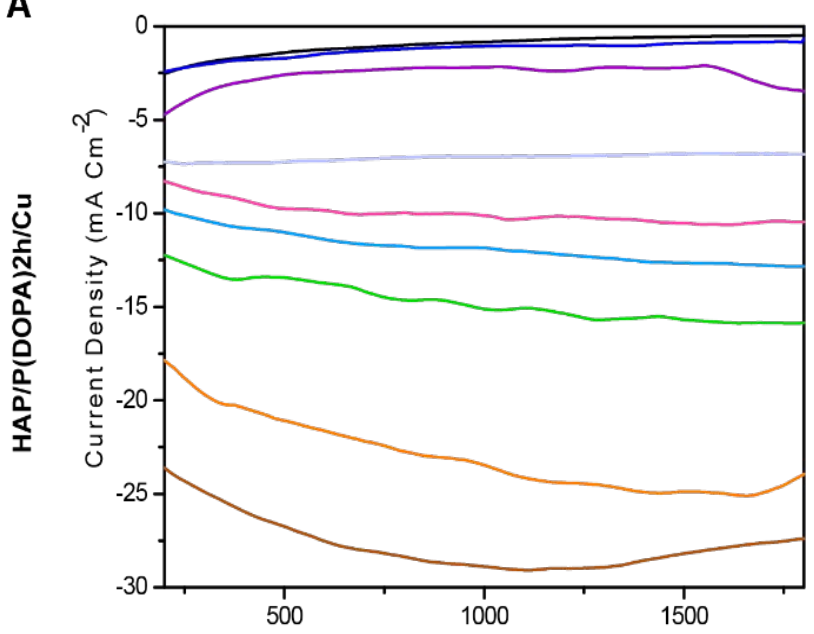

B
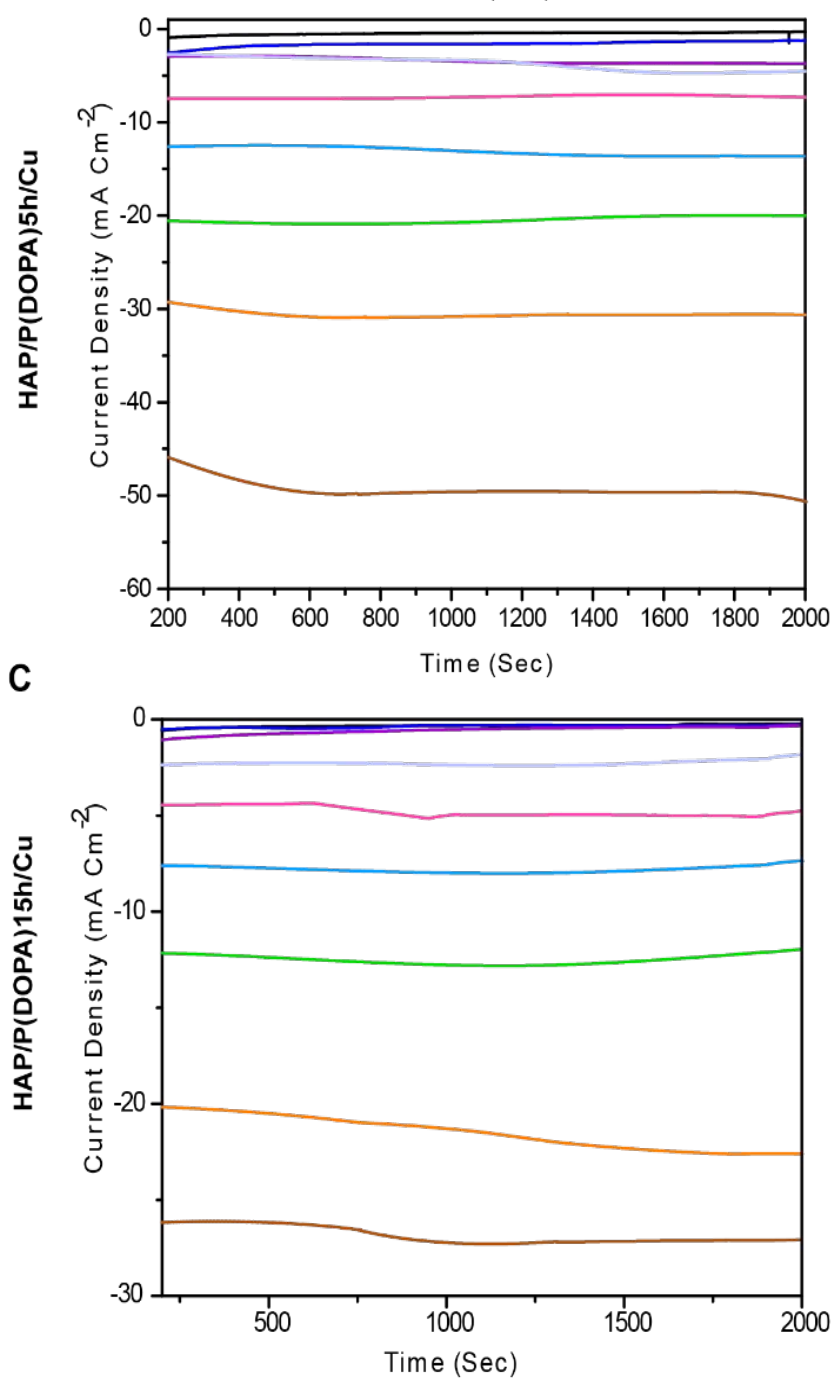
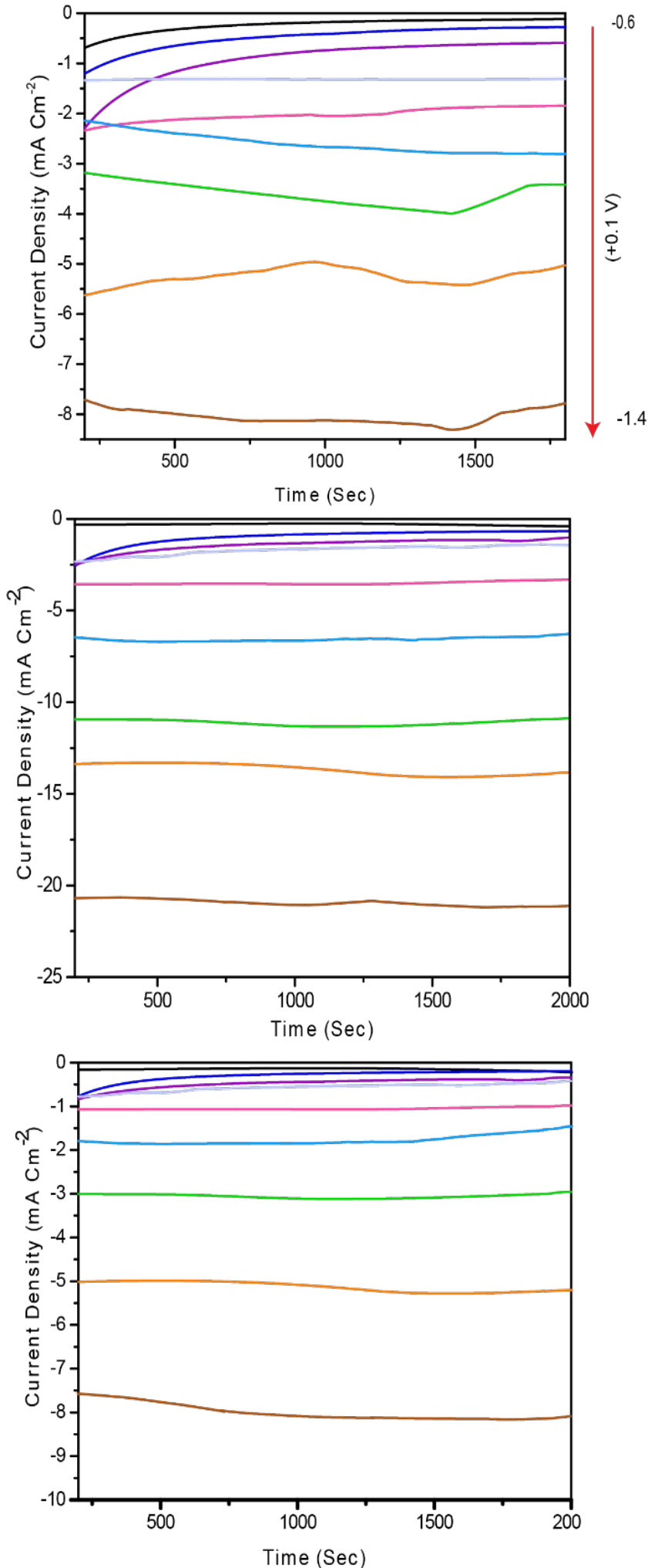

FigureS16. Chronoamperometric responses in $0.1 \mathrm{M} \mathrm{KHCO}_{3}$ solution at different potentials (0.6 to $-1.4 \mathrm{~V}_{\mathrm{RHE}}$ ) for A) $\left.\mathrm{HAP} / \mathrm{P}(\mathrm{DOPA}) 2 \mathrm{~h} / \mathrm{Cu}, \mathrm{B}\right) \mathrm{HAP} / \mathrm{P}(\mathrm{DOPA}) 2 \mathrm{~h} / \mathrm{Cu}$ and $\mathrm{C}$ ) $\mathrm{HAP} / \mathrm{P}(\mathrm{DOPA}) 2 \mathrm{~h} / \mathrm{Cu}$ in both PEC (left panel) and $\mathrm{EC}$ (right panel) analysis modes. 

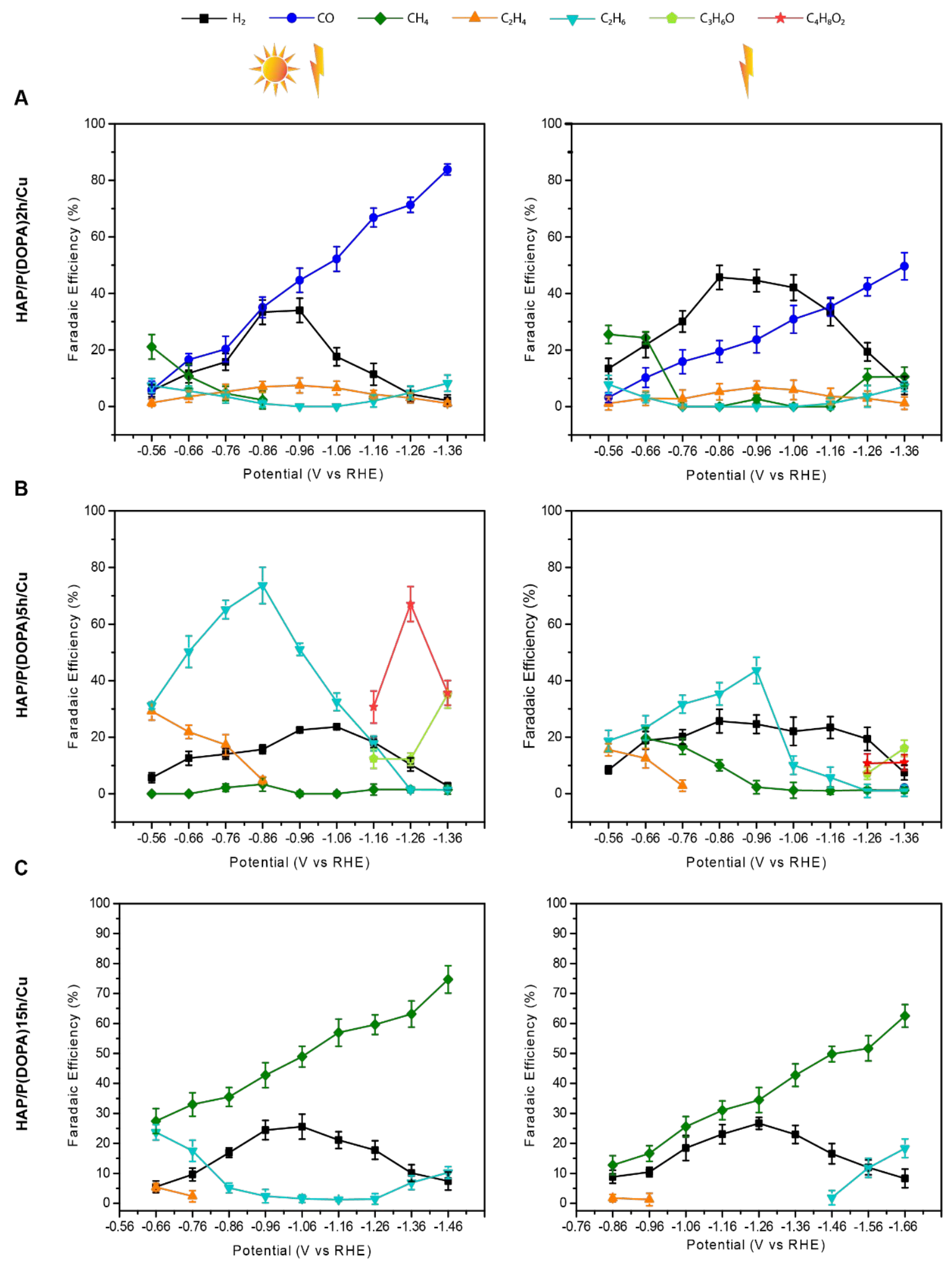

Figure S17. Selectivity (Faradaic efficiency $\left(\mathrm{H}_{2}, \mathrm{CO}, \mathrm{CH}_{4}, \mathrm{C}_{2} \mathrm{H}_{4}, \mathrm{C}_{2} \mathrm{H}_{6}, \mathrm{C}_{3} \mathrm{H}_{6} \mathrm{O}\right.$ and $\left.\mathrm{C}_{4} \mathrm{H}_{8} \mathrm{O}_{2}\right)$ ) of A) HAP/P(DOPA) $2 \mathrm{~h} / \mathrm{Cu}, \mathrm{B}) \mathrm{HAP} / \mathrm{P}(\mathrm{DOPA}) 2 \mathrm{~h} / \mathrm{Cu}$ and C) HAP/P(DOPA) $2 \mathrm{~h} / \mathrm{Cu}$ at different applied potentials in $\mathrm{CO}_{2}$-saturated $0.5 \mathrm{M} \mathrm{KHCO}_{3}$ 


\section{Electrochemical Capacitance Measurements}

Cyclic voltammetry has been done with scan rates ranging from 10 to $150 \mathrm{mV} \mathrm{s}^{-1}$ with an interval of $10-30 \mathrm{mV} \mathrm{s}^{-1}$ at the potential window of $0.1 \mathrm{~V}$ to $0.2 \mathrm{~V}$ vs. RHE (Figure $6 \mathrm{~A}$ ). The double-layer capacitance of the electrocatalyst $\left(\mathrm{C}_{\mathrm{dl}}\right)$, was extracted by plotting $\mathrm{Ja}-\mathrm{Jc}$ (at 0.15

V vs. RHE) versus the scan rate.

The slope of this plot is twice of $\mathrm{C}_{\mathrm{d} l}$. As it can be seen in Figure 6B, the electrochemical double-layer capacitance $\left(\mathrm{C}_{\mathrm{dl}}\right)$ of $\mathrm{HAP} / \mathrm{P}(\mathrm{DOPA}) 5 \mathrm{~h} / \mathrm{Cu}\left(49.9 .1 \mathrm{mF} \mathrm{cm}^{-2}\right)$ was much greater than both that of $\mathrm{HAP} / \mathrm{P}(\mathrm{DOPA}) 2 \mathrm{~h} / \mathrm{Cu}\left(7.6 \mathrm{mF} \mathrm{cm}^{-2}\right)$ and $\mathrm{HAP} / \mathrm{P}(\mathrm{DOPA}) 15 \mathrm{~h} / \mathrm{Cu}\left(0.74 \mathrm{mF} \mathrm{cm}^{-}\right.$ ${ }^{2}$ ), suggesting $\mathrm{HAP} / \mathrm{P}(\mathrm{DOPA}) 5 \mathrm{~h} / \mathrm{Cu}$ owned significantly larger electrochemically active surface area (ESCA). To evaluate the electron-transfer ability of the electrocatalysts, electrochemical impedance spectroscopy (EIS) is also conducted in the frequency range of 0.1 to $1000 \mathrm{~Hz}$. The semicircular characteristic of EIS curves (Nyquist plots) reveals $\mathrm{HAP} / \mathrm{P}(\mathrm{DOPA}) 5 \mathrm{~h} / \mathrm{Cu}$ possesses a much smaller charge transfer resistance (Rct) than $\mathrm{HAP} / \mathrm{P}(\mathrm{DOPA}) 2 \mathrm{~h} / \mathrm{Cu}$ and $\mathrm{HAP} / \mathrm{P}(\mathrm{DOPA}) 15 \mathrm{~h} / \mathrm{Cu}$ (Figure 6C). Usually, the faster charge transfer promotes the formation of $\mathrm{CO}_{2}{ }^{-}$intermediates through the first electron transfer step. Figure 6D presents Tafel plots in both analysis modes (PEC and EC). Tafel slopes explore the rate-determining initial electron transfer to $\mathrm{CO}_{2}$ which forms $\mathrm{CO}_{2} *$ intermediate absorbed on 
the surface. The smaller slope of HAP/P(DOPA) 5h/Cu in both analysis modes (PEC (31.6 mV)

and EC $(36.2 \mathrm{mV}))$ proves its intrinsically better catalytic performance. In fact, the smaller

Tafel slope reveals a more favorable for $\mathrm{CO}_{2}$ activation due to a faster electron transfer rate.

A
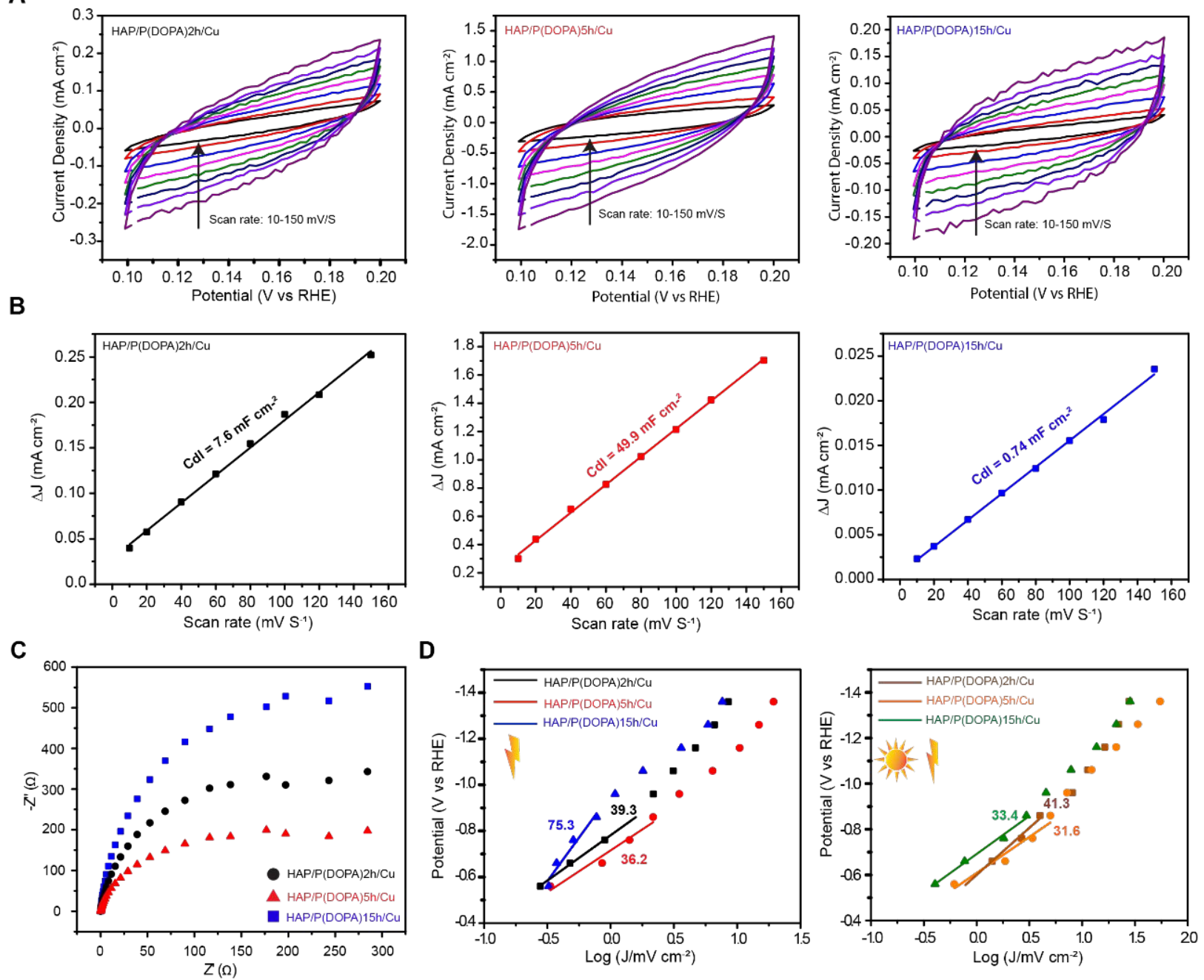

Figure S18. Active surface. A) Cyclic voltammograms (CV) of (HAP/P(DOPA)2h/Cu,

(HAP/P(DOPA)5h/Cu, and (HAP/P(DOPA) $15 \mathrm{~h} / \mathrm{Cu}$ in the region of 0.10-0.20 V vs. RHE at

various scan rates $\left(10-150 \mathrm{mV} \mathrm{s}^{-1}\right)$. B) Electrochemical double-layer capacitance (Cdl) of 
(HAP/P(DOPA)2h/Cu, (HAP/P(DOPA)5h/Cu and (HAP/P(DOPA)15h/Cu. C) Nyquist plots of $(\mathrm{HAP} / \mathrm{P}(\mathrm{DOPA}) 2 \mathrm{~h} / \mathrm{Cu}, \quad(\mathrm{HAP} / \mathrm{P}(\mathrm{DOPA}) 5 \mathrm{~h} / \mathrm{Cu}$ and $(\mathrm{HAP} / \mathrm{P}(\mathrm{DOPA}) 15 \mathrm{~h} / \mathrm{Cu}$ over the frequency ranging from $1000 \mathrm{kHz}$ to $0.1 \mathrm{~Hz}$ at $-0.7 \mathrm{~V}$ vs. RHE (Electrochemical impedance spectroscopy (EIS)). D) The Tafel slope of (HAP/P(DOPA)2h/Cu, (HAP/P(DOPA)5h/Cu and (HAP/P(DOPA) $15 \mathrm{~h} / \mathrm{Cu}$ in both analysis modes (EC and PEC). 


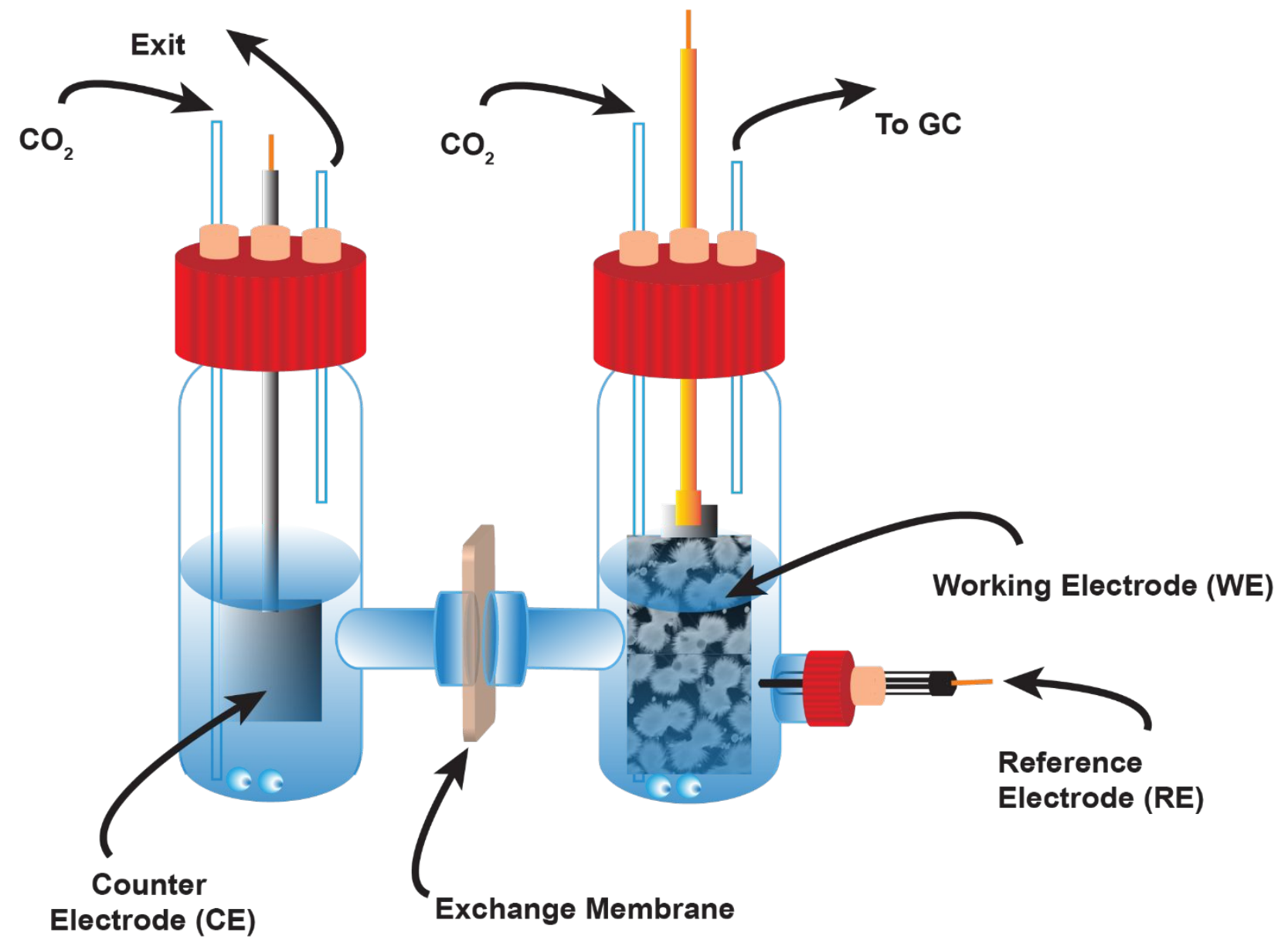

Scheme S1. Schematic diagram of our home-made electrochemical H-type cell. 
A

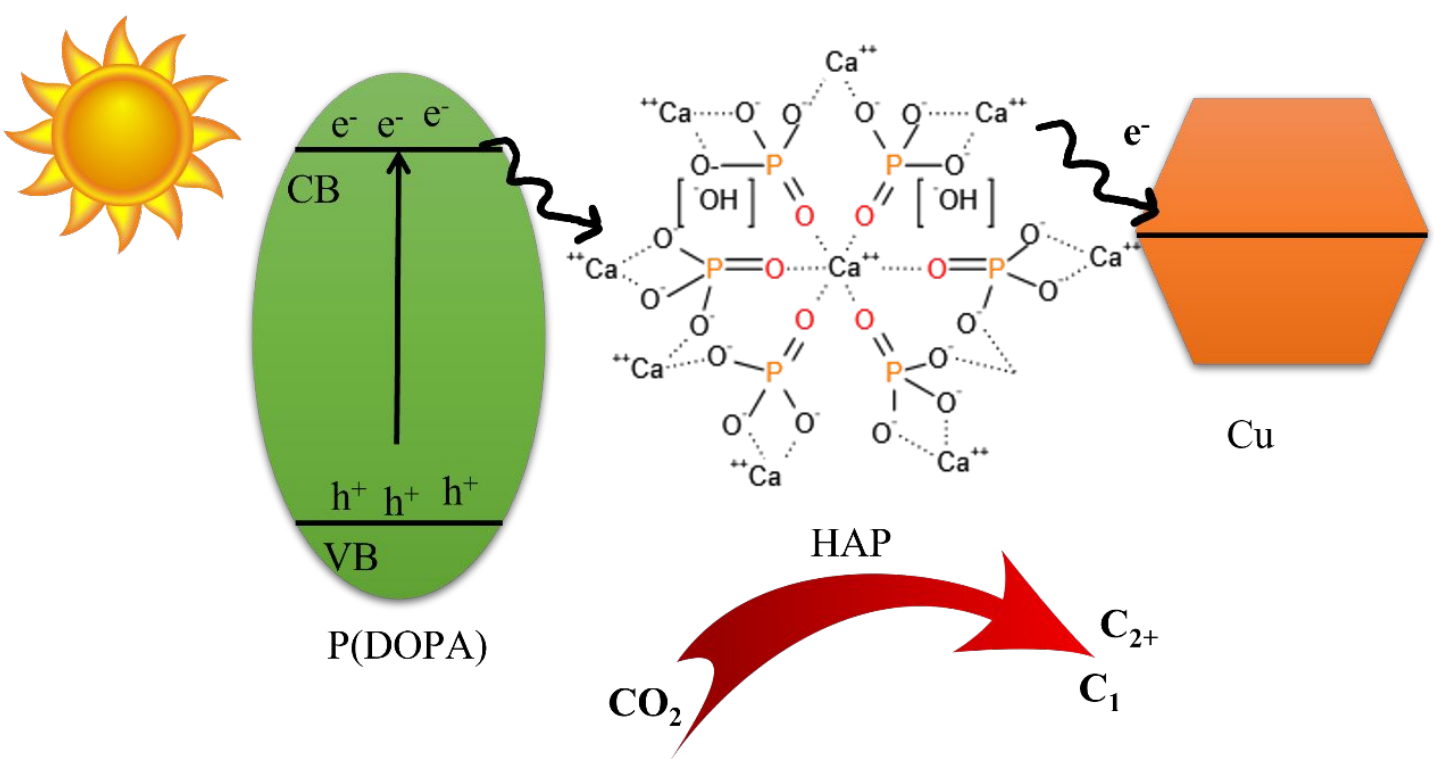

B
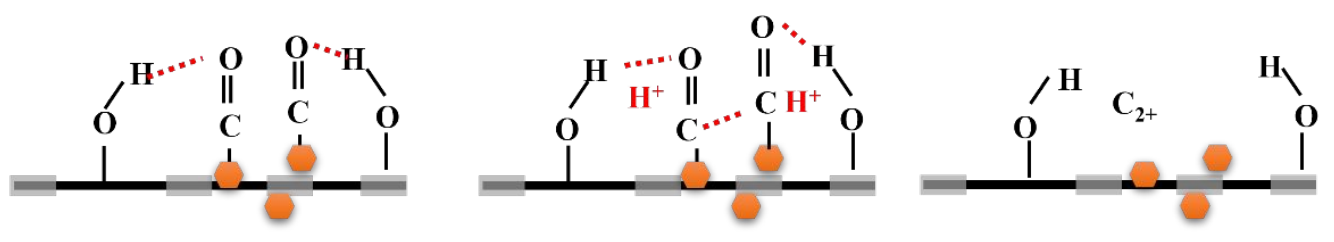

C

i)
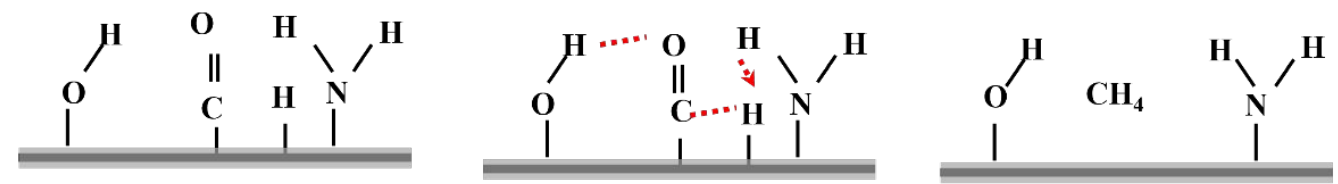

ii)
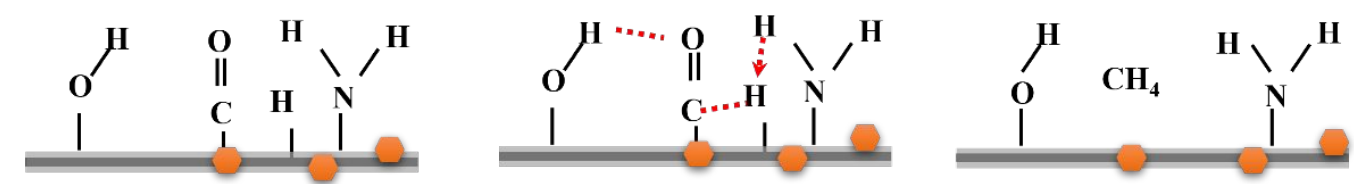

D
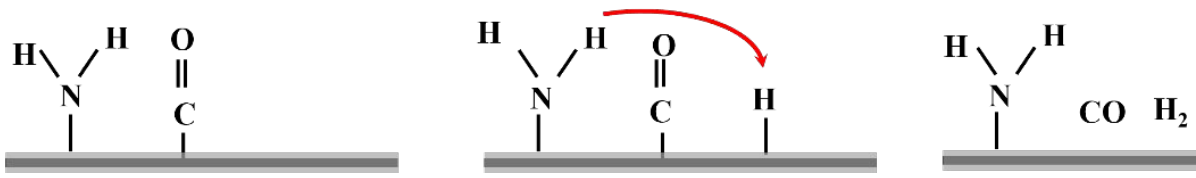

Scheme S2. A) A proposed mechanism of photocatalytic reduction of $\mathrm{CO}_{2}$ over $\mathrm{HAP} / \mathrm{P}(\mathrm{DOPA}) / \mathrm{Cu}$ composite. B-D) The roles of functional groups (HAP and P(DOPA)), $\mathrm{Cu}$ and their synergistic effect on the $\mathrm{CO}_{2}$ reduction catalysis. 
Table S1. Elemental analysis.

\begin{tabular}{lccc||ccc}
\hline & $\mathbf{C u}$ & $\mathbf{P}$ & $\mathbf{C a}$ & $\mathbf{C}$ & $\mathbf{H}$ & $\mathbf{N}$ \\
\hline Catalyst & \multicolumn{3}{c||}{ ICP analysis (\%) } & \multicolumn{3}{|c}{ CHN analysis (\%) } \\
\hline \hline HAP/P(DOPA)2h/Cu & 11.98 & 16.50 & 30.96 & 2.7 & 0.32 & 0.35 \\
HAP/P(DOPA)5h/Cu & 12.79 & 16.81 & 31.76 & 4.35 & 0.37 & 0.61 \\
HAP/P(DOPA)15h/Cu & 12.01 & 14.11 & 27.69 & 10.1 & 0.49 & 1.37 \\
\hline \hline
\end{tabular}


Table S2. Maximum faradaic efficiency of blanks (HAP, HAP/CuO, HAP/P(DOPA)2h, HAP/P(DOPA) $5 \mathrm{~h}, \mathrm{HAP} / \mathrm{P}(\mathrm{DOPA}) 15 \mathrm{~h}$ for each product in both analysis Modes $(\mathrm{P} / \mathrm{EC})$.

\begin{tabular}{|c|c|c|c|c|c|c|c|}
\hline Sample & $\begin{array}{c}\mathrm{H}_{2} \\
(\mathrm{FE} \%) \\
\end{array}$ & $\begin{array}{c}\mathrm{CO} \\
(\mathrm{FE} \%) \\
\end{array}$ & $\begin{array}{c}\mathrm{CH}_{4} \\
(\mathrm{FE} \%) \\
\end{array}$ & $\begin{array}{c}\mathrm{C}_{2} \mathrm{H}_{4} \\
(\mathrm{FE} \%) \\
\end{array}$ & $\begin{array}{c}\mathrm{C}_{2} \mathrm{H}_{6} \\
(\mathrm{FE} \%) \\
\end{array}$ & $\begin{array}{l}\mathrm{C}_{3} \mathrm{H}_{6} \mathrm{O} \\
(\mathrm{FE} \%) \\
\end{array}$ & $\begin{array}{l}\mathrm{C}_{4} \mathrm{H}_{8} \mathrm{O}_{2} \\
(\mathrm{FE} \%) \\
\end{array}$ \\
\hline HAP & $\begin{array}{c}\sqrt{ } \\
(49.8 / 48.7)\end{array}$ & $\begin{array}{c}\sqrt{ } \\
(40.3 / 41.2)\end{array}$ & $\begin{array}{c}\sqrt{ } \\
(6.4 / 3.9)\end{array}$ & ND & ND & ND & ND \\
\hline $\mathrm{HAP} / \mathrm{CuO}$ & $\begin{array}{c}\sqrt{ } \\
(49.3 / 47.6)\end{array}$ & $\begin{array}{c}\sqrt{ } \\
(39.6 / 38.3)\end{array}$ & $\begin{array}{c}\sqrt{ } \\
(17.6 / 14.3)\end{array}$ & $\begin{array}{c}\sqrt{ } \\
(<10)\end{array}$ & $\begin{array}{c}\sqrt{ } \\
(<10)\end{array}$ & ND & ND \\
\hline $\mathrm{HAP} / \mathrm{P}(\mathrm{DOPA}) 2 \mathrm{~h}$ & $\begin{array}{c}\sqrt{ } \\
(49.1 / 28.5) \\
\end{array}$ & $\begin{array}{c}\sqrt{ } \\
(41.1 / 33.2) \\
\end{array}$ & $\begin{array}{c}\sqrt{ } \\
(20.1 / 13.6) \\
\end{array}$ & ND & ND & ND & ND \\
\hline $\mathrm{HAP} / \mathrm{P}(\mathrm{DOPA}) 5 \mathrm{~h}$ & $\begin{array}{c}\sqrt{ } \\
(29.1 / 22.5)\end{array}$ & $\begin{array}{c}\sqrt{ } \\
(15.4 / 8.8) \\
\end{array}$ & $\begin{array}{c}\sqrt{ } \\
(41.7 / 30.7)\end{array}$ & ND & ND & ND & ND \\
\hline $\mathrm{HAP} / \mathrm{P}(\mathrm{DOPA}) 15 \mathrm{~h}$ & $\begin{array}{c}\sqrt{ } \\
(27.4 / 21.6)\end{array}$ & ND & $\begin{array}{c}\sqrt{ } \\
(57.6 / 41.8)\end{array}$ & ND & ND & ND & ND \\
\hline
\end{tabular}

ND: Not detected 
Table S3. The periodic quantification of products during long-term stability test.

\begin{tabular}{|c|c|c|c|c|c|c|c|c|c|}
\hline \multirow{2}{*}{ Electrocatalyst } & \multirow{2}{*}{ Products } & \multirow{2}{*}{$\begin{array}{l}\text { Analysis } \\
\text { Mode }\end{array}$} & \multicolumn{6}{|c|}{ FE (\%) } & \multirow{2}{*}{$\begin{array}{l}\text { Total FE } \\
\text { drop }(\%)\end{array}$} \\
\hline & & & $\overline{~ 1 \mathrm{~h}}$ & $2 \mathrm{~h}$ & $3 \mathrm{~h}$ & 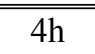 & $\overline{5 h}$ & $\overline{~ 6 h}$ & \\
\hline \multirow{2}{*}{$\mathrm{HAP} / \mathrm{P}(\mathrm{DOPA}) 2 \mathrm{~h} / \mathrm{Cu}$} & \multirow{2}{*}{$\mathrm{CO}$} & EC & 35.89 & 35.15 & 34.76 & 34.65 & 33.11 & 32.58 & 9.2 \\
\hline & & PEC & 66.51 & 64.28 & 61.94 & 58.15 & 56.08 & 52.41 & 21.2 \\
\hline \multirow{2}{*}{$\mathrm{HAP} / \mathrm{P}(\mathrm{DOPA}) 5 \mathrm{~h} / \mathrm{Cu}$} & \multirow{2}{*}{$\mathrm{C}_{2} \mathrm{H}_{6}$} & $\mathrm{EC}$ & 6.78 & 6.63 & 6.58 & 6.42 & 6.36 & 6.21 & 8.4 \\
\hline & & PEC & 19.46 & 19.11 & 18.65 & 18.01 & 17.83 & 17.58 & 9.7 \\
\hline \multirow{2}{*}{$\mathrm{HAP} / \mathrm{P}(\mathrm{DOPA}) 15 \mathrm{~h} / \mathrm{Cu}$} & \multirow{2}{*}{$\mathrm{CH}_{4}$} & $\mathrm{EC}$ & 35.72 & 35.25 & 34.95 & 34.15 & 33.59 & 32.81 & 8.1 \\
\hline & & PEC & 57.98 & 56.63 & 55.42 & 54.50 & 53.15 & 51.94 & 10.4 \\
\hline
\end{tabular}


Table S4: The comparison of catalysts based on hydroxyapatite or polydopamine in various $\mathrm{CO}_{2}$ conversion systems

\begin{tabular}{|c|c|c|c|c|}
\hline Photo/catalyst & Product & Method & Comments & Ref \\
\hline "HAP & $\begin{array}{l}\mathrm{CO} \\
\mathrm{HCOOH}\end{array}$ & Electrochemical & $\begin{array}{l}\text { J: } 18 \mathrm{~mA} \mathrm{Cm}^{-2} \\
\text { FE: } 7.2 \%(\mathrm{CO}) \text { and } 76.6 \%(\mathrm{HCOOH}) \\
\text { E: }-0.86(\mathrm{~V} \text { vs RHE })\end{array}$ & $\overline{99}$ \\
\hline CuNWs@PDA & $\mathrm{CH}_{4}$ & Electrochemical & $\begin{array}{l}\mathrm{J}: 20 \mathrm{~mA} \mathrm{Cm}^{-2} \\
\text { FE: } \sim 30 \% \\
\text { E: }-0.97 \text { (V vs RHE) }\end{array}$ & 10 \\
\hline Cu-HAP & $\mathrm{CO}$ & Photothermal & $\begin{array}{l}\mathrm{CO}_{2} \text { Conversion: } 61.29 \% \\
\text { Selectivity: } 99.73 \%\end{array}$ & 11 \\
\hline Polarized-HAP & $\mathrm{C}_{2} \mathrm{H}_{5} \mathrm{OH}$ & Electrothermal & $\begin{array}{l}\mathrm{CO}_{2} \text { Conversion: } 0.08 \% \\
\text { Selectivity: } \sim 90 \%\end{array}$ & 12 \\
\hline $\mathrm{HAP} / \mathrm{TiO}_{2}$ & $\mathrm{CH}_{4}$ & Photochemical & Selectivity: $>95 \%$ & 13 \\
\hline Cu-HAP & $\mathrm{CO}$ & $\begin{array}{l}\text { Photochemical } \\
\text { Hydrogenation }\end{array}$ & CO production rate: $215 \mu \mathrm{mol} / \mathrm{g} / \mathrm{h}$ & 14 \\
\hline $\mathrm{PDA} 15 / \mathrm{ZnO} / \mathrm{Co}_{3} \mathrm{O}_{4}$ & $\mathrm{CO}$ & Photochemical & $\begin{array}{l}\text { CO production rate: } 537.5 \mu \mathrm{mol} / \mathrm{g} / \mathrm{h} \\
\text { CO selectivity: } 97.7 \%\end{array}$ & 15 \\
\hline $\mathrm{TiO}_{2} @ P D A$ & $\begin{array}{l}\mathrm{CH}_{4} \\
\mathrm{CH}_{3} \mathrm{OH}\end{array}$ & Photochemical & $\begin{array}{l}\mathrm{CH}_{4} \text { production rate: } 1.50 \mu \mathrm{mol} / \mathrm{h} / \mathrm{g} \\
\mathrm{CH}_{3} \mathrm{OH} \text { production rate: } 0.26 \mu \mathrm{mol} / \mathrm{h} / \mathrm{g}\end{array}$ & 16 \\
\hline Ti/TiO 2 NT@PDA-AgNP & $\mathrm{CH}_{3} \mathrm{OH}$ & Photoelectrochemical & $\begin{array}{l}\mathrm{J}: \sim 3 \mathrm{~mA} \mathrm{Cm}^{-2} \\
\text { FE: } 78 \% \\
\mathrm{E}:-0.7(\mathrm{~V} \text { vs } \mathrm{Ag} / \mathrm{AgCl}) \\
\mathrm{CH}_{3} \mathrm{OH} \text { production rate: } 508.57 \mu \mathrm{mol} / \mathrm{cm}^{2} / \mu \mathrm{g}\end{array}$ & 17 \\
\hline HAP/P(DOPA)/Cu & $\begin{array}{l}2 \mathrm{~h}: \mathrm{CO} \\
\\
5 \mathrm{~h}: \\
\mathrm{C}_{2} \mathrm{H}_{6} \\
\mathrm{C}_{4} \mathrm{H}_{8} \mathrm{O}_{2}\end{array}$ & Photoelectrochemical & $\begin{array}{l}\text { J: } 22 \mathrm{~mA} \mathrm{Cm}^{-2} \\
\text { FE: } 83.8 \%(\mathrm{CO}) \\
\text { E: }-1.36(\mathrm{~V} \text { vs RHE }) \\
\text { J: } 10 \mathrm{~mA} \mathrm{Cm}-2,35 \mathrm{~mA} \mathrm{Cm}^{-2} \\
\text { FE: } 73.7 \%\left(\mathrm{C}_{2} \mathrm{H}_{6}\right) \text { and } 67.1 \%\left(\mathrm{C}_{4} \mathrm{H}_{8} \mathrm{O}_{2}\right) \\
\text { E }\left(\mathrm{C}_{2} \mathrm{H}_{6}\right):-0.86(\mathrm{~V} \text { vs RHE}) \\
\text { E }\left(\mathrm{C}_{4} \mathrm{H}_{8} \mathrm{O}_{2}\right):-1.26(\mathrm{~V} \text { vs RHE}) \\
\text { J: } 30 \mathrm{~mA} \mathrm{Cm}-2 \\
\text { FE: } 62.51 \%\left(\mathrm{CH}_{4}\right) \\
\text { E: }-1.46(\mathrm{~V} \text { vs RHE })\end{array}$ & $\begin{array}{l}\text { This } \\
\text { Work }\end{array}$ \\
\hline
\end{tabular}

HAP: Hydroxyapatite

PDA \& P(DOPA): Polydopamine

NT: Nanotube 


\section{References}

1. Kuhl, K. P.; Cave, E. R.; Abram, D. N.; Jaramillo, T. F., New insights into the electrochemical reduction of carbon dioxide on metallic copper surfaces.Energy \& Environmental Science 2012, 5 (5), 7050-7059.

2. MacDonald, A. M. G., The oxygen flask method. A review.Analyst 1961, 86 (1018), 3-12.

3. Liebscher, J.; Mrówczyński, R.; Scheidt, H. A.; Filip, C.; Hădade, N. D.; Turcu, R.; Bende, A.; Beck, S., Structure of Polydopamine: A Never-Ending Story?Langmuir 2013, 29 (33), 10539-10548.

4. Nguyen, D. N.; Sim, U.; Kim, J. K., Biopolymer-Inspired N-Doped Nanocarbon Using Carbonized Polydopamine: A High-Performance Electrocatalyst for HydrogenEvolution Reaction.Polymers 2020, 12 (4), 912.

5. Yamini, D.; Devanand Venkatasubbu, G.; Kumar, J.; Ramakrishnan, V., Raman scattering studies on PEG functionalized hydroxyapatite nanoparticles.Spectrochimica Acta Part A: Molecular and Biomolecular Spectroscopy 2014, 117, 299-303.

6. Luo, F.; Wu, K.; Shi, J.; Du, X.; Li, X.; Yang, L.; Lu, M., Superior flame retardancy and high thermal conductivity.Journal of Materials Chemistry A 2017, 5 (35), 18542-18550. 7. Zangmeister, R. A.; Morris, T. A.; Tarlov, M. J., Characterization of polydopamine thin films deposited at short times by autoxidation of dopamine.Langmuir 2013, 29 (27), 8619-8628.

8. Gheisari, H.; Karamian, E.; Abdellahi, M., A novel hydroxyapatite -Hardystonite nanocomposite ceramic.Ceramics International 2015, 41 (4), 5967-5975.

9. $\quad$ Coskun, H.; Aljabour, A.; De Luna, P.; Farka, D.; Greunz, T.; Stifter, D.; Kus, M.; Zheng, X.; Liu, M.; Hassel, A. W.; Schöfberger, W.; Sargent, E. H.; Sariciftci, N. S.; Stadler, P., Biofunctionalized conductive polymers enable efficient $\mathrm{CO}<\mathrm{sub}>2</$ sub $>$ electroreduction.Science Advances 2017, 3 (8), e1700686.

10. Liu, H.; Xiang, K.; Liu, Y.; Zhu, F.; Zou, M.; Yan, X.; Chai, L., Polydopamine Functionalized $\mathrm{Cu}$ Nanowires for Enhanced CO2 Electroreduction Towards Methane.ChemElectroChem 2018, 5 (24), 3991-3999.

11. Guo, J.; Duchesne, P. N.; Wang, L.; Song, R.; Xia, M.; Ulmer, U.; Sun, W.; Dong, Y.; Loh, J. Y. Y.; Kherani, N. P.; Du, J.; Zhu, B.; Huang, W.; Zhang, S.; Ozin, G. A., HighPerformance, Scalable, and Low-Cost Copper Hydroxyapatite for Photothermal CO2 Reduction.ACS Catalysis 2020, 10 (22), 13668-13681.

12. Sans, J.; Revilla-López, G.; Sanz, V.; Puiggalí, J.; Turon, P.; Alemán, C., Permanently polarized hydroxyapatite for selective electrothermal catalytic conversion of carbon dioxide into ethanol.Chemical Communications 2021, 57 (42), 5163-5166.

13. Chong, R.; Fan, Y.; Du, Y.; Liu, L.; Chang, Z.; Li, D., Hydroxyapatite decorated $\mathrm{TiO} 2$ as efficient photocatalyst for selective reduction of $\mathrm{CO} 2$ with $\mathrm{H} 2 \mathrm{O}$ into CH4.International Journal of Hydrogen Energy 2018, 43 (49), 22329-22339.

14. Guo, J.; Liang, Y.; Song, R.; Loh, J. Y. Y.; Kherani, N. P.; Wang, W.; Kübel, C.; Dai, Y.; Wang, L.; Ozin, G. A., Construction of New Active Sites: Cu Substitution Enabled Surface Frustrated Lewis Pairs over Calcium Hydroxyapatite for $\mathrm{CO} 2$ Hydrogenation.Advanced Science 2021, 8 (17), 2101382.

15. Li, M.; Zhang, S.; Li, L.; Han, J.; Zhu, X.; Ge, Q.; Wang, H., Construction of Highly Active and Selective Polydopamine Modified Hollow ZnO/Co3O4 p-n Heterojunction Catalyst for Photocatalytic CO2 Reduction.ACS Sustainable Chemistry \& Engineering 2020, 8 (30), 11465-11476. 
16. Meng, A.; Cheng, B.; Tan, H.; Fan, J.; Su, C.; Yu, J., TiO2/polydopamine S-scheme heterojunction photocatalyst with enhanced CO2-reduction selectivity.Applied Catalysis B: Environmental 2021, 289, 120039.

17. Perini, J. A. L.; Torquato, L. D. M.; Irikura, K.; Zanoni, M. V. B., Ag/polydopaminemodified Ti/TiO2 nanotube arrays: A platform for enhanced $\mathrm{CO} 2$ photoelectroreduction to methanol.Journal of CO2 Utilization 2019, 34, 596-605. 